\title{
Acordos de paz para a América Central nos anos 1980: a busca pela solução negociada*
}

\section{Peace accords in Central America in the 1980s: efforts for negotiated settlement}

Vanessa Braga Matijascic ${ }^{1}$

* Recebido em: 25/10/2014.

Aprovado em: 03/01/2015.

1 Professora de Relações Internacionais na Fundação Armando Alvares Penteado (FAAP). Doutora em História e mestre e bacharel em Relações Internacionais pela Universidade Estadual Paulista "Júlio de Mesquita Filho". Para entrar em contato: vanessa.matijascic@gmail. com. Esta é uma versão adaptada do capítulo 2 da tese de doutorado apresentada ao Programa de Pós-graduação em História da Universidade Estadual Paulista "Júlio de Mesquita Filho" (UNESP, campus Franca) em 2014, sob orientação da professora Dr. Suzeley Kalil Mathias. A pesquisa foi possível com os financiamentos Fulbright e CAPES, especialmente quando conduzida entre setembro de 2012 e maio de 2013. O período compreendeu o estágio de pesquisa no exterior no Center for Security Studies em Georgetown University, sob co-orientação da professora Dr. Margaret Daly Hayes.

E-mail: monalisavbm@gmail.com.

\section{Resumo}

As negociações de paz na América Central nos anos 1980 envolveram uma série de iniciativas diplomáticas que contemplaram o Grupo de Contadora e o Grupo de Apoio a Contadora, o grupo de países de Tegucigalpa e, por fim, o desfecho proposto pelas cúpulas centro-americanas. O foco da política externa de Ronald Reagan, norteado pela aniquilação das guerrilhas, incentivou os países de Contadora a evitar a busca da solução militar. O objetivo deste estudo é possibilitar a compreensão sobre como as iniciativas de Contadora ofereceram outro caminho que, quando deparadas pelo escândalo Irã-contras, possibilitou o encaminhamento das cúpulas centro-americanas para o desfecho negociado e pacífico. Para a realização do estudo foi feita revisão bibliográfica e uso de fontes primárias resultantes dos diversos encontros diplomáticos.

Palavras-chave: América Central. Contadora. Estados Unidos. Nicarágua.

\begin{abstract}
The peace negotiations in Central America in the 1980s involved many diplomatic initiatives, which contemplated the Contadora Group and the Contadora Support Group, the group of Tegucigalpa, and finally, the outcome proposed by the Central American summits. The Ronald Reagan's foreign policy goal, guided by the annihilation of the guerrillas, encouraged the countries of the Contadora Group to avoid military solution. The aim of this study is to provide a better understanding of how the Contadora initiatives offered another path to peace after Iran-contra scandal. For this goal, this study contemplates literature review and primary sources resulting from various diplomatic meetings.
\end{abstract}

Keywords: Central America. Contadora. United States. Nicaragua. 


\section{Introdução}

Durante a administração do presidente republicano Ronald Reagan (1981-1989), a orientação da política externa dos Estados Unidos elegeu a sua tradicional área de influência, a América Central e Caribe, como região prioritária para o combate ao comunismo, demonstração de força e superioridade militar dos Estados Unidos e promoção da retomada do "exercício hegemônico do poder no âmbito da comunidade internacional" (TREIN, 1983, p. 62). A motivação vislumbrada foi impedir que El Salvador se tornasse a terceira perda estratégica, depois da segunda - Nicarágua em 1979, com o avanço dos sandinistas ${ }^{2}$ - e Cuba, quando Fidel Castro anunciou alinhamento com a União Soviética em 1961. Todas as guerrilhas centro-americanas tinham o regime cubano, primeira perda estratégica dos Estados Unidos, como grande inspiração revolucionária. Para estancar a expansão desta ameaça comunista, a administração Reagan orientou-se por esforços políticos no intuito de obter aprovação de orçamentos com a finalidade de capacitar exércitos locais para exterminar as guerrilhas e demover qualquer projeto político revolucionário do poder. Assim, a escalada do conflito leste-oeste na América Central preocupou os governantes de demais países latino-americanos que queriam evitar que as Américas fossem novo palco de confronto entre as potências da Guerra Fria.

A abordagem do contexto histórico sobre as negociações regionais para alcançar a paz na América Central, contrapondo-se a solução militar dos Estados Unidos, é o objetivo desse estudo. Pretende-se proporcionar a compreensão de quais iniciativas diplomáticas propuseram a solução negociada, quem esteve envolvido com os processos de paz, quais eram os interesses de cada país e como cada um influenciou as negociações. Acima de tudo, entre as

2 Os sandinistas eram aqueles que compunham a Frente Sandinista de Libertação Nacional (FSLN) e promoveram a revolução sandinista a partir de 1979. A FSLN surgiu em 1961, inspirou-se na figura de Augusto César Sandino, responsável por coordenar a insurgência contra os fuzileiros navais da intervenção militar dos Estados Unidos na Nicarágua (19121933). A FSLN foi fundada por estudantes nicaraguenses que pertenceram ao partido comunista e se inspiraram na vitória do Movimento Cubano de 26 de Julho. A FSLN reuniu grupos radicais estudantis como: a Juventude Democrática Nicaraguense (ligada ao partido comunista), a Juventude Revolucionária Nicaraguense e a Juventude Patriótica Nicaraguense (ZIMMERMANN, 2006, p. 28-47). inúmeras iniciativas regionais, é importante salientar quais delas esmoreceram e quais de fato vingaram. Ademais, explorar-se-á, ao longo do texto, a atuação dos Estados Unidos como desagregador da iniciativa diplomática de Contadora, incentivando pontualmente outras negociações protagonizadas por países aliados da América Central.

Desenvolve-se a redação do estudo numa trajetória linear dos acontecimentos, começando pela iniciativa de Contadora, prosseguindo com as negociações de Esquipulas, abordando as reuniões de cúpula centro-americanas e finalizando com o envolvimento da Organização das Nações Unidas (ONU) e da Organização dos Estados Americanos (OEA) nos processos de implementação dos compromissos assumidos.

Não se utilizou uma metodologia específica, pois a finalidade de nossa abordagem é trazer ao conhecimento do leitor os principais arranjos diplomáticos desse importante momento histórico, bem como a maneira como as iniciativas regionais tentaram se contrapor à escalada militar na região. Salienta-se que recuperar tais fatos contempla a necessidade de se continuar a desenvolver pesquisas que possam avaliar o impacto dos acordos de paz dos anos 1980 para a América Central no contexto pós-Guerra Fria.

\section{Antecedentes de Contadora}

Os acordos de paz na América Central nos anos 1980 foram diversos e de diferentes arranjos, sendo os principais o latino-americano (Grupo de Contadora e Grupo de Apoio a Contadora/Grupo de Lima) e o centro-americano (Grupo de Tegucigalpa). Pode-se afirmar que em ambos os casos buscaram-se alternativas de negociação para o fim das hostilidades entre guerrilhas e exércitos nacionais seguido da desmobilização dos grupos armados e viabilização de processos de transição para governos democráticos.

No início de 1983, a pioneira iniciativa de Contadora foi liderada pelo México, que se mostrou disposto a convergir posições e buscar proposições na órbita latino-americana para solucionar os problemas no istmo ${ }^{3}$. Essa atitude foi importante para diminuir a possibilidade

Istmo é uma porção terrestre estreita que conecta duas grandes extensões territoriais, cercada por água dos dois lados. Especificamente, o istmo do Panamá interliga a América Central/Norte à América do Sul, sendo banhado pelo mar caribenho e pelo Oceano Pacífico. É recorrente na literatura especializada o uso da expressão países do istmo como equivalente a países centro-americanos. 
da solução armada, além de frear a escalada do conflito regional para um confronto mais amplo, que confirmasse o continente americano como palco de confronto direto da Guerra Fria.

O impasse de posições entre a Nicarágua e os Estados Unidos protelou o encaminhamento e êxito planejado pelo México com a Ata de Paz de Contadora, em 1984. A clivagem de posições políticas entre os próprios países centro-americanos fez com que, ao longo das negociações de Contadora, eles se reunissem em foro separado para discutir questões mais pontuais. Dessa maneira, formou-se o Grupo de Tegucigalpa, composto principalmente pelos presidentes da Costa Rica, El Salvador e Honduras.

Enquanto Contadora perfilava o caminho quixotesco, o presidente Ronald Reagan (1981-1989) nomeou Henry Kissinger, em julho de 1983, como líder da Comissão Bipartidária Nacional para a América Central (CBNAC) - National Bipartisan Commission on Central America - também conhecida como Comissão Kissinger. O objetivo da CBNAC foi construir o consenso partidário para respaldar a política externa da administração Reagan para a América Central. Isso ocorreu porque existiam posições divergentes entre a Câmara dos Representantes, com maioria do Partido Democrata, e o Senado, em sua maioria composto por senadores do Partido Republicano. A Câmara dos Representantes apresentava resistência quanto à aprovação de orçamento para assistência militar aos governos e grupos contrários às guerrilhas organizadas em El Salvador, Guatemala e Nicarágua. Tal posição representava a crítica dos democratas em relação à condução da política externa de Reagan que precisou de apoio Legislativo para aprovar orçamentos para profissionalizar os exércitos locais. Todavia, indiretamente, essa assistência militar promoveu a escalada do conflito ideológico na América Central e vislumbrava a solução armada (vitória militar) em detrimento da solução pacífica e negociada. Portanto, financiar a contrainsurgência era a estratégia da gestão Reagan para pôr fim ao furor revolucionário no istmo.

Tal contexto foi devidamente explorado pela diplomacia mexicana para conduzir as negociações de Contadora em momentos propensos, quando as disputas no Legislativo e entre departamentos governamentais atinentes às questões centro-americanas nos Estados Unidos deixavam a presidência deste país menos predisposta a influenciar ou desarticular as negociações de Contadora com os países centro-americanos.
Entende-se das palavras de Caraveo Toledo (1984) que El Salvador, Guatemala e Nicarágua foram países nos quais deflagraram guerras civis, pois as desigualdades sociais foram agudas e a capacidade (ou vontade) de captação das demandas sociais pelo poder político era pequena. Assim, as clivagens sociais provenientes de uma estrutura econômica excludente e de baixa representatividade política impulsionaram a formação de grupos armados e guerrilhas que pretendiam depor os governos oligárquicos. Tais antagonismos sociais e econômicos existiram também nas Honduras e na Costa Rica ${ }^{4}$, mas não resultaram na formação de grupos guerrilheiros que iniciaram a revolta armada. Assim, não eram o foco da contrainsurgência de Reagan e eram países aliados para as manobras militares ou apoio político.

Ainda que a Costa Rica e as Honduras não tivessem realidade semelhante aos países vizinhos, estavam envolvidos com a crise na América Central, pois, em decorrência da revolução sandinista, grupos da oposição nicaraguense - os contras ${ }^{5}$ - cruzaram as fronteiras da Nicarágua para articularem, a partir dos territórios hondurenho e costa-riquenho, a deposição do governo revolucionário sandinista. Em maior quantidade, os contras estiveram nas Honduras, enquanto um grupo menor abrigava-se ao norte e ao nordeste da Costa Rica (VICKERS, 1995).

Não se ignora o fato de que a deterioração do quadro político, culminando em crise regional, esteve associada aos fatores externos de natureza econômica. Reconhece-se que as economias dos países centro-americanos estiveram ainda mais vulneráveis às oscilações do comércio internacional, principalmente quando diminuiu a exportação dos produtos nos quais os países

4 As Honduras não acumularam os problemas de El Salvador, como a concentração fundiária e alta densidade populacional. Por sua vez, a Costa Rica foi destacada no relatório da CBNAC como exemplo de caminho democrático a ser seguido pelos demais países. Pode-se dizer que parte dessa estabilidade política está relacionada com a abdicação das forças de defesa nos anos 1940, distanciando-se das instabilidades resultantes da politização dos militares que acometeu os países vizinhos (ROUQUIÉ, 1994).

5 O esforço contrarrevolucionário foi amparado militarmente (treinamento e logística) por aqueles, os contras, que se opunham à derrubada de lideranças conservadoras no entorno geográfico (em específico, queriam reverter o que os sandinistas conquistaram), tendo o apoio político e financeiro dos Estados Unidos para a execução de uma investida armada (ROUQUIÉ, 1994, passim). 
centro-americanos eram mais competitivos. Além disso, como agravante, o segundo choque do preço do petróleo em 1979, aumentou a dependência econômica ${ }^{6}$.

Ainda que tenha existido essa agravante oriunda da esfera econômica, enfatiza-se que a estrutura do sistema político conservador na Nicarágua, El Salvador e Guatemala excluiu as reivindicações populares, abafadas diversas vezes pelos exércitos nacionais no século XX. A oligarquia desses países ignorou as comunidades indígenas, os movimentos sociais e a questão fundiária. A combinação da excludente desigualdade social, com a concentração de riquezas em poucas famílias e a baixa representatividade política possibilitou que grupos guerrilheiros, inspirados no exemplo da Revolução Cubana (1959), almejassem a construção de nova realidade nacional. Na clandestinidade, os guerrilheiros organizaram-se e armaram-se até chegar o momento propício de romperem com a continuidade dos privilégios oligárquicos. $\mathrm{O}$ contexto da Guerra Fria contribuiu acentuando a polarização política.

O estopim da crise regional foi a revolução sandinista, sendo o fim da "era Somoza" também comemorado e visto como benéfico por países latino-americanos. Por outro lado, existiu o temor de que a revolução, tal como a cubana, se encaminhasse para o socialismo. Para evitar esse caminho, o México, a Venezuela e os Estados Unidos ofereceram cooperação econômica à Nicarágua (OJEDA GÓMEZ, 2007, p. 18). No entanto, a despeito dessa iniciativa, os sandinistas progrediram no caminho ideológico da revolução e não restavam dúvidas de que a política externa de Reagan confrontaria a qualquer custo, econômico e político, a saída dos sandinistas no poder para impedir a expansão comunista na região (LYNCH, 2011).

Com exceção da Costa Rica, que desde o final dos anos 1940 era uma democracia liberal representativa ${ }^{7}$, todos os demais países tiveram regimes políticos autori-

6 México e Venezuela negociaram melhores condições de venda de petróleo para os países da América Central e Caribe em 3 de agosto de 1980. A finalidade do Acuerdo Petrolero de San José foi minimizar o impacto da crise de 1979 para a economia desses países (OJEDA GÓMEZ, 2007, p. 23).

7 Pode-se brevemente entender a democracia liberal representativa como um conjunto de regras que dá certeza ao que será alcançado ao longo do processo e respeito aos resultados, quanto ao exercício do poder pelo representante eleito por sufrágio universal e que irá perseguir os interesses da nação (BOBBIO, 1986). tários $^{8}$ nos anos 1930 e 1940: em El Salvador, Maximiliano Hernández Martínez (1931-1944); na Guatemala, Jorge Ubico (1931-1944); nas Honduras, Tiburcio Carias Andinos (1933-1949); e na Nicarágua, os Somoza (19361979). Pode-se dizer que, mesmo quando tais governos não estavam mais em exercício, a estrutura de poder de baixa representatividade se manteve. Principalmente no início da Guerra Fria, a manutenção dos militares como participantes da política dos países centro-americanos foi apoiada pelos Estados Unidos como contendores de manifestações populares e desmanteladores de movimentos de esquerda com inclinação comunista (CARAVEO TOLEDO, 1984, p. 43-45).

Dessa maneira, mesmo com toda a conjuntura que favoreceu a repressão, as manifestações de descontentamento popular cresceram, bem como a articulação entre as guerrilhas em El Salvador, Guatemala e Nicarágua. Acompanhando esse movimento, o regime cubano articulou-se para prestar auxílio aos guerrilheiros centro-americanos empenhados em pegar em armas para depor os governos conservadores. O ápice da crise aconteceu nos anos 1980, quando a América Central foi escolhida pela administração Reagan como área prioritária de contenção do avanço comunista ${ }^{9}$. Para evitar a solução militar, os países latino-americanos decidiram articular a paz pela via diplomática.

Antecipadamente, propõe-se expor os interesses, as necessidades e a conjuntura dos países do istmo quanto às iniciativas diplomáticas de Contadora para se alcançar a paz na América Central. Inicia-se pela Guatemala

8 Os regimes políticos autoritários são aqueles nos quais não estão asseguradas as liberdades políticas e individuais, os governantes permanecem no poder por golpe de Estado e há suspensão do sufrágio universal. Trata-se do oposto ao que são os regimes políticos democráticos nos quais existem eleições livres e com candidatos de partidos políticos que competem entre si, sendo os eleitos no Executivo e Legislativo pelo voto da maioria dos eleitores. Ademais, nos regimes políticos democráticos as liberdades políticas e individuais estão asseguradas pela Carta Magna que é redigida contendo as regras de funcionamento do Estado e onde se registram os direitos civis e sociais dos cidadãos (BOBBIO; MATTEUCCI; PASQUINO, 1998, p. 1081-1083).

9 O coordenador do Conselho de Segurança Nacional dos Estados Unidos entre os anos de 1981 e 1982, Richard Vincent Allen, decidiu redistribuir as respostas de demonstração de força de Washington e considerou a América Latina e, em específico, a América Central e o Caribe regiões que passariam de "pátio traseiro" a "pátio dianteiro" (MAIRA, 1982, p. 205206). 
que adotou uma postura neutra ${ }^{10}$ durante as negociações. A gestão do presidente Brigadeiro Óscar Humberto Mejía Victores (1983-1986) colocou como meta encaminhar a transição para a democracia o mais rápido possível com o objetivo de minimizar o risco da Unidade Revolucionária Nacional Guatemalteca (URNG) ${ }^{11}$ receber auxílio do governo sandinista, tal como acontecia com a Frente Farabundo Martí de Libertação Nacional (FMLN) ${ }^{12}$. Assim, Marco Vinicio Cerezo Arévalo, candidato do Partido Democrata Cristão, foi eleito e esteve na presidência até 1991 (DANA SIMS; PETRASH, 1987, p. 6).

Em El Salvador, independente da iniciativa diplomática, o país já estava em guerra civil desde 1980. Sendo assim, interessava ao presidente José Napoleón Duarte que o exército salvadorenho conseguisse vitória militar contra a FMLN, sendo o apoio dos Estados Unidos - principalmente o financiamento militar e econômico - imprescindível para respaldar o governo salvadorenho

10 Salienta-se também o fato de que os Estados Unidos exerceram pressão na Guatemala para que houvesse mudança de regime de governo. Uma das formas de isolar diplomaticamente a Guatemala e a Nicarágua foi pedindo para que a Costa Rica não convidasse os dois países para participar da reunião da Comunidade Democrática Centro-americana, celebrada em San José, em 16 de janeiro de 1982 (OJEDA GÓMEZ, 2007, p. 24). A partir desse momento, a diplomacia dos Estados Unidos exerceu pressão no governo guatemalteco para que deixasse sua postura neutra quanto ao processo de paz de Contadora e reuniões do Grupo de Tegucigalpa (OJEDA GÓMEZ, 2007, p. 21).

11 A Unidade Revolucionária Nacional da Guatemala (URNG) unificou, em janeiro de 1982, os quatro grupos guerrilheiros que já existiam: (1) Exército Guerrilheiro dos Pobres (EGP), fundado em 1973 por Roland Morán; (2) as Forças Armadas Revolucionárias (FAR), criadas por Pablo Monsanto em 1962; (3) a Organização Revolucionária do Povo Armado (ORPA), formada por Rodrigo Asturias em 1972; e (4) o Partido Comunista, conhecido como Partido Guatemalteco dos Trabalhadores (PGT), que surgiu em 1949 e recebeu esse último nome (PGT), em 1952 (Cf: BATISTA, 2003).

12 Semelhante ao processo da Nicarágua, a FMLN reuniu aqueles que eram contra os interesses da elite econômica e do regime militar institucional (1948-1979). A inspiração da FMLN norteou-se pela figura de um líder popular que foi Agustín Farabundo Martí Rodríguez, contemporâneo de Sandino. Martí teve uma trajetória de engajamento político com estudantes e camponeses que não queriam mais a exploração dos grupos dominantes. A atuação política de Martí, com o levante de camponeses em 1932, incomodou o presidente e general Maximiliano Hernández Martínez (1931-1944). O líder Martí e os integrantes do levante de 1932 foram mortos pela repressão organizada pelo general Hernández Martínez. O sangrento episódio ficou conhecido como La Matanza, quando se estimou que mais de 20 mil pessoas foram mortas pelo exército (MONTGOMERY; WADE, 2006, p. 26-42). contra as guerrilhas. Os interesses dos governos salvadorenhos nos anos 1980 (Duarte e Cristiani) nas negociações de paz estiveram vinculados com a guerra civil, pois, se os sandinistas saíssem do poder aceitando o caminho democrático na Nicarágua, naturalmente isso eliminaria o apoio logístico sandinista às guerrilhas salvadorenhas, o que colaboraria para o fim da guerra civil.

Em Honduras, a partir de 1980, a Constituição do país favoreceu a volta do regime democrático de governo. Roberto Suazo Córdoba (1982-1986) foi o primeiro presidente civil depois de anos de governos militares. $\mathrm{O}$ território hondurenho era importante por fazer fronteira com El Salvador, Nicarágua e Guatemala. A posição de Honduras nos processos de negociação era delicada, pois a oposição aos sandinistas denominada Frente Democrática Nacional (FDN) - parte dos contras - recebiam financiamento dos Estados Unidos. Tal como El Salvador, os recursos nas áreas econômica e militar eram importantes para as Honduras conterem os sandinistas na hipótese de haver expansão revolucionária e para protegerem o território as fronteiras da FMLN. Assim, as razões para continuar apoiando a administração Reagan iam ao encontro das necessidades na área de segurança e defesa nas Honduras (DANA SIMS; PETRASH, 1987, p. 7). Por outro lado, se os processos de paz pudessem encaminhar uma transição de regime político na Nicarágua, as Honduras também seriam beneficiadas ${ }^{13}$.

A Costa Rica, por sua vez, mantinha uma política estável desde 1948. Sorto (2001, p. 182) argumentou que a crise centro-americana mudou a tradicional política de neutralidade do país e a Costa Rica passou a apoiar os Estados Unidos, fortalecendo a desarticulação de Contadora. Em decorrência dessa posição, o país rompeu relações diplomáticas com Cuba em 1981, passou a praticar uma política hostil contra os sandinistas e apoiou o governo do presidente Duarte. O temor quanto à revolução sandinista era que o furor revolucionário ultrapassasse os limites fronteiriços e desestabilizasse o país. Já que Costa Rica não tinha forças armadas ${ }^{14}$, a decisão do

13 O primeiro abalo nas relações entre Honduras e Nicarágua ocorreu quando a Guarda Nacional de Somoza decidiu refugiar-se em território hondurenho. Em agosto de 1980, o ministro das relações exteriores de Honduras foi até Manágua para assegurar ao governo sandinista de que o governo e as autoridades do país impediriam que esse contingente promovesse ataques contra a Nicarágua (OJEDA GÓMEZ, 2007, p. 19).

14 A administração do presidente José María Hipólito Figueres Ferrer (1948-9) aboliu as forças armadas e instaurou uma guarda civil (ALCÁNTARA SÁEZ, 2008, p. 117). 
governo foi a de autorizar a presença de forças de defesa dos Estados Unidos. Duas organizações dos contras: a Aliança Revolucionária Democrática (ARDE) e a FDN também estavam em território costa-riquenho nas regiões fronteiriças com a Nicarágua, situadas a nordeste. Declarando apoio aos Estados Unidos, a Costa Rica recebeu financiamento econômico, militar e incremento de forças de defesa em 1985 (DANA SIMS; PETRASH, 1987, p. 7). Durante o governo do presidente Luis Alberto Monge (1982-1986), a Costa Rica foi, assim, desagregadora da Ata de Paz de Contadora.

A mudança de postura política, que se configurou por maior autonomia do país perante os desafios regionais, aconteceu durante a gestão do social-democrata presidente Óscar Arias Sánchez. Arias tornou-se o grande articulador de um novo processo de paz entre os países centro-americanos e conseguiu resultados mais efetivos a partir de Esquipulas II, em 1987. Em questões domésticas, Arias proibiu a utilização do território costa-riquenho pelos contras e fez oposição à "política belicista dos Estados Unidos” (SORTO, 2001, p.183).

O governo dos Estados Unidos suspendeu ajuda econômica à Nicarágua, uma vez que a revolução ganhou contornos ideológicos. Dessa maneira, os sandinistas expandiram relações com outros países europeus e países comunistas. Acima de tudo, o país recebeu uma vasta ajuda militar da União Soviética para defender-se de uma possível incursão militar dos Estados Unidos e dos contras. Além disso, o governo sandinista auxiliou no treinamento de jovens milicianos pró-revolução para os países vizinhos, incluindo as Honduras e a Costa Rica (DANA SIMS; PETRASH, 1987, p. 7). A Nicarágua criou muita resistência ao longo das negociações de Contadora com a finalidade de contrapor-se aos Estados Unidos. Porém, essa postura foi revista quando a iniciativa do Plano Arias propôs uma solução centro-americana para os problemas da região. Ademais, esse já era um momento que até mesmo a Internacional Socialista pedia para que a Nicarágua ingressasse com mais seriedade nas negociações de acordos de paz, rumo ao caminho democrático (HARTO DE VERA, 1991, p. 213-14).

Segundo Dana Sims e Petrash (1987, p. 7-8), parte dos países que compuseram o Grupo de Contadora também tinham interesses nas negociações para a paz. $\mathrm{O}$ articulador do Grupo de Contadora, o México, sempre esteve envolvido com a América Central, principalmente para incentivar a independência política e econômica dos países da região, em contraposição à dependência e influência dos Estados Unidos. A Venezuela, preocupada em dar apoio à promoção da democracia no Caribe e na América Central, decidiu participar do Grupo de Contadora, pois tinha receio de que houvesse intervenção militar dos Estados Unidos em países da região. A Colômbia participou com o intuito de promoção da democracia; estava preocupada com a polarização seja por parte dos Estados Unidos ou de Cuba na região e, principalmente, ingressou em Contadora para não permitir que somente existisse influência da Venezuela na questão regional, uma vez que a rivalidade entre os países manifestou-se muitas vezes no campo das relações exteriores. Por fim, o Panamá teve duas razões que motivaram o ingresso no Grupo: a primeira estava relacionada com a demarcação de certa independência dos Estados Unidos em assuntos regionais e a segunda motivação alicerçou-se na contenção dos sandinistas quanto à expansão da revolução para os demais países (OJEDA GÓMEZ, 2007).

Como se pode notar, diversos foram os interesses que impulsionaram os países latino-americanos na direção de uma solução que pudesse atenuar a corrida armamentista na região. Numa visão otimista, a ambição era selar os primeiros acordos de paz que colocassem fim à regionalização do conflito leste-oeste. Entre os diversos discursos que auxiliaram no desenvolvimento desse processo, tendo em vista diminuir tensões entre os Estados Unidos e a Nicarágua, está o do presidente do México, José López Portillo (1976-1982), quando foi convidado a receber um prêmio do governo sandinista em fevereiro de 1982. O presidente Portillo sinalizou que seria importante os Estados Unidos deixarem as ameaças de fazer uso da força contra a Nicarágua e parassem de financiar os contras. O presidente mexicano também defendeu a necessidade dos sandinistas diminuírem o contingente militar e insistiu que a Nicarágua deveria assinar um compromisso de não agressão com os países vizinhos e com os Estados Unidos (MIRANDA; RATLIFF, 1994, p. 256).

Pouco tempo depois desse pronunciamento, que não despertou interesse dos Estados Unidos e da Nicarágua, o ministro das relações exteriores de Honduras propôs, na discussão da agenda da OEA, em março do mesmo ano, a desmilitarização da região, a não intervenção militar e a verificação internacional de acordos a serem celebrados (MIRANDA; RATLIFF, 1994, p. 257).

Em maio de 1982, uma nova reunião da Comunidade Democrática Centro-americana foi sugerida pelos Estados Unidos. Dessa vez, a diplomacia estaduniden- 
se estava interessada em convidar o Panamá para saber sobre o posicionamento político do país frente aos processos de paz. O presidente panamenho, Arístides Royo (1978-1982), declarou que não era aceitável nenhuma iniciativa de paz regional que excluísse algum dos países do istmo (CALLONI; CRIBARI, 1983, p. 1 apud OJEDA GÓMEZ, 2007, p. 17).

Meses depois, em setembro, México e Venezuela insistiram em evitar exclusão de países em um acordo regional e emitiram um comunicado ao presidente Reagan sobre a necessidade de promover um programa de cooperação entre os países da América Central. Por sua vez, a administração Reagan queria evitar a liderança latino-americana e ignorou o comunicado desses países. Por meio do subsecretário de Estado de Assuntos Interamericanos, Thomas Enders, a administração Reagan incentivou a Costa Rica a promover um encontro, que aconteceu em 8 de outubro de 1982, sob o título de Fórum para a Paz e a Democracia, em San José. Quando convidada, a Nicarágua recusou-se a participar por se tratar de um encontro a pedido dos Estados Unidos. Dessa maneira, o México e a Venezuela também decidiram não ir, pois não participariam de um encontro sobre cooperação regional sem a presença da Nicarágua. (DANA SIMS; PETRASH, 1987, p. 9). Assim, participaram do encontro em San José: Costa Rica, El Salvador e Honduras e, na condição de membros observadores, Belize, Colômbia, Panamá e República Dominicana (OJEDA GÓMEZ, 2007, p. 28).

Com a posse do novo presidente mexicano, $\mathrm{Mi}$ guel de la Madrid, no início de dezembro de 1982, os esforços de negociação ganharam força. Em primeiro lugar, a responsabilidade por um acordo era dos países centro-americanos e existia dificuldade para alcançá-lo por causa dos diferentes interesses dos países, além do poder que os Estados Unidos tinham em desagregar iniciativas regionais que incluíssem a Nicarágua. Assim, o México sabia que era importante contar com outros países latino-americanos para oferecer alternativas e soluções aos países centro-americanos. Nesse caso, um enviado especial do governo do México reuniu-se com representantes da Colômbia, Venezuela e Panamá para saber qual seria a melhor abordagem. No geral, os países compreenderam que não se deveria pensar apenas na guerra civil salvadorenha ou nos problemas de fronteira entre as Honduras e a Nicarágua. O melhor acordo seria aquele que desse uma solução de alcance regional à crise, contemplando todos os países. Dessa maneira, o Panamá ofereceu que seu país pudesse sediar o primeiro encontro dos países de Contadora para o início de janeiro de 1983 (OJEDA GÓMEZ, 2007, p. 37-8).

\section{Grupo de Contadora e Grupo de Apoio à Contadora}

Em 1979, com o incremento no foco para a contrainsurgência por parte da política externa dos Estados Unidos, especialmente após as diretrizes anunciadas pela administração Ronald Reagan, os países latino-americanos convergiram esforços para auxiliar na busca da paz na América Central e evitar a solução armada. Segundo Mallmann (2008, p. 83):

Em janeiro de 1983, México, Venezuela, Colômbia e Panamá uniram os esforços que vinham despendendo isoladamente na busca de uma solução não violenta para a crise centro-americana. Naquela ocasião, foi criado o Grupo Contadora, tendo por objetivo geral encontrar, no marco de uma gestão latino-americana, saída pacífica para os complexos problemas políticos regionais.

O Grupo de Contadora foi formado após a reunião dos ministros das relações exteriores do México, Venezuela, Colômbia e Panamá, que aconteceu na Ilha de Contadora, no golfo panamenho, nos dias 8 e 9 de janeiro de 1983. O objetivo do encontro era convergir posições e alcançar uma solução pacífica para a crise centro-americana que eclodiu após a ascensão dos sandinistas na Nicarágua.

O Grupo de Contadora pretendia ponderar a atuação armada das guerrilhas em Nicarágua e El Salvador e reduzir a influência cubana e soviética na região, amenizando a tensão criada pelo conflito leste-oeste no istmo (BAGLEY, 1986, p. 3). Essa iniciativa diplomática era vista com receio pelos Estados Unidos, pois a via pacífica não contemplava a manutenção dos contras para depor o governo dos sandinistas e o esforço para conformar consenso poderia propiciar a trapaça dos sandinistas nas negociações de maneira a terem mais tempo para fortalecerem o governo e articular deposições em outros países.

A expectativa do Grupo de Contadora era incentivar a transição do regime político sandinista e desmobilizar os contras. Essa era a questão central e mais difícil de ser resolvida. Nos encontros dos ministros das relações exteriores na ilha de Contadora, o ímpeto era prover "soluções latino-americanas para os problemas latino-americanos" (BAGLEY, 1986, p. 2). Logo, entende-se que a iniciativa se fortaleceu principalmente para evitar inter- 
venções militares (solução armada dos Estados Unidos) na Nicarágua e em El Salvador.

O processo de paz de Contadora pode ser dividido em quatro fases (BAGLEY, 1986; VICKERS, 1995): a primeira aconteceu de janeiro a setembro de 1983, quando os ministros das relações exteriores dos países de Contadora reuniram-se com os representantes dos países centro-americanos com a finalidade de ouvir as necessidades de cada país, obter respaldo às negociações multilaterais e desenvolver uma carta de princípios para alcançar a solução pacífica. Quando o Grupo de Contadora completou um ano em janeiro de 1984, houve divisões dos representantes dos países em comissões temáticas: segurança regional, questões políticas e cooperação econômica e social. Pretendia-se com isso fazer com que os países dialogassem e chegassem a entendimentos de maneira que o processo da redação do acordo de paz pudesse ser mais direcionado e feito em menor espaço de tempo.

A segunda fase caracterizou-se pela vontade da Nicarágua de assinar a Ata de Paz de Contadora desde que houvesse revisões, momento esse que perdurou entre meados dos meses de setembro dos anos 1983 e 1984. Nesse mesmo ano, todos os países centro-americanos estavam envolvidos com o Grupo de Contadora e a Ata produzida a partir desses encontros chegou a versão preliminar em 7 de setembro de 1984.

A terceira fase, que foi de outubro de 1984 a dezembro de 1985, caracterizou-se pelo impasse entre a Nicarágua e os Estados Unidos. O primeiro pediu suspensão por seis meses das negociações dos acordos de paz porque havia relutância dos Estados Unidos em cumprir com a suspensão do financiamento aos contras. Este, por sua vez, desconfiou do rápido movimento do governo sandinista, concordando com a assinatura da Ata sob a condição de que os Estados Unidos parassem de financiar os contras, se a Nicarágua assinasse a Ata de Paz de Contadora.

Por fim, na quarta fase, entre janeiro e junho de 1986, existiram avanços que culminaram com a Declaração de Caraballeda ${ }^{15}$, na qual ficou registrado o comprometimento pela paz, segurança e democracia na América Central. Todavia, em 6 de junho de 1986, os países de

15 MENSAJE de Caraballeda para la paz, la seguridad y la democracia de América Central. Venezuela, 12 de enero de 1986. Disponível em: <http://biblio3.url.edu.gt/Publi/Libros/Acuerdos-de-Paz/04.pdf>. Acesso em: 20 jan. 2014.
Contadora e Grupo de Apoio à Contadora (Argentina, Brasil, Peru e Uruguai) atingiram o próprio limite estabelecido pelos mediadores no início das negociações para se chegar ao acordo final (BAGLEY, 1986; VICKERS, 1995). Com a data limite posta e o fim das negociações de Contadora, a Câmara dos Representantes dos Estados Unidos não pôde mais ser relutante e aprovou o novo orçamento para auxiliar os contras (BAGLEY, 1986, p.4).

\section{As negociações de Contadora}

López Hernández (1993, p. 94) afirmou que o início das negociações de Contadora caracterizou-se pelo convite aos ministros de relações exteriores do Grupo para visitarem os cinco países da região durante os dias 12 e 13 de abril de 1983. Nessas visitas, os chanceleres de Contadora ouviram opiniões e proposições de como deveriam ser conduzidas as negociações de paz na América Central. O primeiro encontro após esses procedimentos de consultas foi em abril de 1983, no Panamá.

O clima favorável ao entendimento na segunda e na terceira reuniões fez com que a maioria dos países centro-americanos apresentasse propostas para uma agenda de paz em julho de 1983. Ao contrário da maioria, a Nicarágua não estava interessada em comprometer-se com os pontos que versaram sobre a desmobilização das guerrilhas, principalmente porque a revolução sandinista ganhou força e as eleições para a escolha presidencial aconteceriam no ano seguinte. Assim, os sandinistas saberiam se a população referendaria essa opção política deflagrada em 1979.

Percebe-se que a desmobilização das guerrilhas, condição importante para a pacificação, não era desejada pela Nicarágua, e havia o impasse entre esse país e os Estados Unidos. Como exemplo dos compromissos a serem assumidos, negligenciados pela Nicarágua, está a Declaração de Cancun, de 17 de julho de 1983, que foi posteriormente, em novembro de 1983, apoiada pela ONU e OEA (DANA SIMS; PETRASH, 1987, p. 11):

- Compromisso para por término a toda situação de beligerância prevalecente;

- Compromisso para o congelamento no nível de armamentos ofensivos existentes;

- Compromisso para a iniciação de negociações sobre acordos de controle e redução no inventário atual de armamentos, com a constituição de mecanismos adequados de supervisão;

- Compromisso de proscrição a existência de 
instalações militares de outros países em seu território; $[\ldots]$

- Compromisso de estabelecer mecanismos internos de controle para impedir o tráfico de armas do território de qualquer país da região até território de outro

- Compromisso de promover um clima de distensão e de confiança na área, evitando declarações e outras ações que ponham em perigo o indispensável clima de confiança política que se requer;

- Compromisso de coordenar sistemas de comunicação direta entre os governos a fim de prever conflitos armados e de gerar uma atmosfera de confiança política recíproca ${ }^{16}$.

O projeto da Ata de Contadora para a Paz e Cooperação na América Central foi discutida de junho a setembro de 1984, totalizando doze meses de esforços desde o início das negociações até a redação preliminar. Em 9 de junho, foi criada a primeira versão que teve ajustes até 7 de setembro de 1984. Os extensos pontos reunidos na Ata estão em sequência assim consignados: nos compromissos gerais (a) renúncia da ameaça da força contra a integridade territorial; (b) não ingerência em assuntos internos de outros Estados; (c) respeito à soberania; (d) abstenção de coerção militar, política e econômica.

Sobre os compromissos de assuntos políticos, destaca-se da Ata (a) a promoção da confiança mútua, e (b) a ênfase na propaganda em favor do término da violência e da guerra. Acerca dos processos de reconciliação nacional, acordou-se sobre (c) adotar medidas de aperfeiçoamento do sistema democrático representativo; (d) refe-

16 Tradução livre. "- Compromiso para poner término a toda situación de beligerancia prevaleciente;

- Compromiso para la congelación en el nivel de armamentos ofensivos existentes;

- Compromiso para la iniciación de negociaciones sobre acuerdos de control y reducción en el inventario actual de armamentos, con la constitución de mecanismos adecuados de supervisión;

- Compromiso de proscribir la existencia de instalaciones militares de otros países en su territorio; [...]

- Compromiso de establecer mecanismos internos de control para impedir el trasiego de armas desde el territorio de cualquier país de la región hacia territorio de otro;

- Compromiso de promover un clima de distensión y de confianza en el área, evitando declaraciones y otras acciones que pongan en peligro el indispensable clima de confianza política que se requiere;

- Compromiso de coordinar sistemas de comunicación directa entre los gobiernos a fin de prever conflictos armados y de generar una atmósfera de confianza política recíproca." Disponível em: <http://www.memoriapoliticademexico.org/ Textos/7CRumbo/1983CPC.html>. Acesso em: 12 dez. 2013. rendar e ampliar as normas legais que oferecessem anistia aos cidadãos.

Outros pontos importantes para o processo de paz versaram sobre os compromissos para deter a corrida armamentista, não autorizar a instalação de bases ou escolas militares estrangeiras (e remover as existentes numa alusão a Escola das Américas ${ }^{17}$ ), eliminar o tráfico de armas e proibir o apoio de forças irregulares.

A Ata de Paz de Contadora foi redigida de forma a reunir compromissos importantes para a pacificação, essenciais para o término da crise regional e com medidas importantes para os presidentes implementarem em escala interna. Todavia, a intransigência da Nicarágua e dos Estados Unidos desagregou a conformação das assinaturas. Consequentemente, sem a assinatura e adesão dos compromissos por parte da Nicarágua, a Ata de Paz seria irrelevante.

A situação doméstica nos Estados Unidos e as posições políticas que precederam a Ata de Paz de Contadora foram uma resposta à configuração da maioria partidária em cada uma das esferas decisórias. O Senado, com maioria de republicanos, lidou mal com a resistência da Nicarágua em viabilizar o programa de desarmamento. Assim, o Senado aprovou em abril de 1984, o pedido de 21 milhões de dólares para os contras. Todavia, a Câmara dos Representantes - de maioria democrata - não aprovou esse orçamento. Somado a esse fator doméstico, o presidente do México, Miguel de la Madrid, fez uma visita ao presidente Reagan, em maio do mesmo ano, para pedir que os Estados Unidos iniciasse diálogo com o presidente da Nicarágua com a finalidade de respaldar às negociações de Contadora (GREENBERGER, 1984a).

No início de junho, o secretário de Estado, George Schultz, fez uma visita surpresa ao presidente da Nicarágua para iniciar as conversas sobre o que seria possível

17 A Escola das Américas funcionou no Panamá entre os anos 1946 e 1984, com a finalidade de proporcionar treinamento militar para os oficiais latino-americanos e caribenhos. Naquele contexto, a preocupação da Doutrina de Segurança Nacional dos Estados Unidos era a insurgência comunista nos países abaixo do México, logo, o treinamento oferecido nesse período era o da contrainsurgência. Posteriormente, o nome e a sede da Escola das Américas foram mudados: o Instituto do Hemisfério Ocidental para a Cooperação em Segurança, vinculado ao Departamento de Defesa dos Estados Unidos, foi transferido para a Geórgia. O endereço eletrônico do Instituto está disponível em: <http://www.benning. army.mil/tenant/whinsec/>. Acesso em: 13 dez. 2013. 
para viabilizar Contadora. Entre os pedidos, o secretário de Estado solicitou que a Nicarágua reduzisse armamento militar, cessasse relações nas áreas militares e de segurança com a União Soviética e Cuba, deixasse de auxiliar as guerrilhas em El Salvador e permitisse que o pluralismo democrático adentrasse a Nicarágua. A condução das negociações bilaterais entre os países continuaram em Manzanillo, no México (GREENBERGER, 1984b apud BAGLEY, 1986, p. 8).

Após diversos encontros, os Estados Unidos queriam que a Nicarágua se comprometesse com a suspensão de acordos militares com a União Soviética, bem como com a cessação da importação de armamento, a redução do efetivo militar em 60 mil soldados, a eliminação de parte do arsenal militar, o fim de ajuda às guerrilhas em El Salvador, o início do diálogo entre grupos políticos internos sob a supervisão e a facilitação do Grupo de Contadora. A contrapartida solicitada pela Nicarágua aos Estados Unidos era suspender apoio aos contras, cessar as manobras militares em até um mês, fechar as instalações militares em até seis meses e suspender os programas de apoio militar às Honduras e a El Salvador (GOODFELLOW, 1986, p. 14 apud BAGLEY, 1986, p. 8-9). Com essas condições, Nicarágua assinaria a Ata de $\mathrm{Paz}$ de Contadora.

A administração Reagan ficou surpresa e desconfiada com as solicitações da Nicarágua, pois os prazos para retirada de ajuda militar dos Estados Unidos deveriam acontecer antes do que havia sido prometido pelos sandinistas. Isso fez com que os Estados Unidos suspeitassem do cumprimento do que foi acordado pela Nicarágua e, principalmente, de como seria possível para o Grupo de Contadora verificar e punir violações à Ata de Paz. A administração Reagan resolveu não concordar inteiramente com o que Nicarágua pediu e mobilizou aliados regionais a acordarem e redigirem outra Ata de Paz (TAUBMAN, 1984 apud BAGLEY, 1986, p. 9). Assim, os países centro-americanos não aceitaram a proposta sandinista (DANA SIMS; PETRASH, 1987, p. 11).

A flexibilização por parte da Nicarágua provocou efeito positivo com a comunidade internacional, pois sinalizou que os sandinistas estavam propensos a negociar. Todavia, o Departamento de Estado era resistente em acreditar que finalmente os sandinistas poderiam ceder e cooperar para a mudança de rumos no país e região, logo, resolveu tratar a versão da Ata de Paz de Contadora como versão preliminar e não definitiva do acordo. Isso causou irritação por parte da diplomacia mexicana e des- contentamento por parte do Grupo de Contadora, pois afirmavam que a versão alcançada era a definitiva (BAGLEY, 1986, p. 10).

Contrapondo-se às expectativas de consenso da aceitação da Ata de Paz de Contadora, novas reuniões entre os Estados Unidos e aliados regionais foram realizadas em Tegucigalpa. Assim, a administração Reagan iniciou um processo de consultas em setembro de 1984 com Honduras, El Salvador, Guatemala e Costa Rica sobre a revisão de alguns pontos da Ata de Paz de Contadora. Os aliados - Honduras, El Salvador e Costa Rica - acordaram que era necessário rever alguns itens da Ata de Contadora e reuniram-se a partir de outubro do mesmo ano. Guatemala seguiu acompanhando os encontros como membro observador já que sua posição era neutra. Nesse mês, o prazo final para consolidar a Ata de Paz de Contadora já havia expirado e essa conjuntura pôde encaminhar o curso de outras negociações (GOODFELLOW, 1986, p. 15 apud BAGLEY, 1986, p. 10).

Os ministros das relações exteriores das Honduras, El Salvador e Costa Rica estavam de acordo com algumas objeções a Ata de Paz de Contadora e começaram a elaborar um rascunho para uma nova versão de acordo, a Ata de Tegucigalpa em 19 de outubro de 1984. Nessas reuniões, a Guatemala também esteve presente, mas não quis aderir à versão preliminar do acordo, mantendo-se na neutralidade. Naturalmente, a Nicarágua opôs-se claramente aos encontros e ao que fosse acordado na capital das Honduras (OJEDA GÓMEZ, 2007, p. 67).

A Ata de Tegucigalpa, ou Documento de Tegucigalpa, chegou à versão final em setembro de 1985. Estava acordado entre esses países que estaria proibido manobras militares internacionais na região e seria importante criar um grupo ad hoc para o desarmamento, com representantes de cada país. Com essas medidas, esperava-se que fosse possível parar a aquisição de armas que contribuíam para a escalada do conflito regional, principalmente pretendia-se frear a aquisição de novos equipamentos de combate soviéticos pela Nicarágua. Ademais, o prazo estabelecido para a eliminação de bases militares estrangeiras seria de 90 dias, tempo esse mais extenso do que aquele proposto pela Nicarágua (OJEDA GÓMEZ, 2007, p. 68-69; DANA SIMS; PETRASH, 1987, p. 13).

O grupo de Tegucigalpa era a alternativa que os Estados Unidos tinham para alcançar medidas em detrimento do que foi proposto pela Ata de Paz de Contadora. Além disso, os Estados Unidos exploravam o fato de que 
o Grupo de Contadora era apenas uma iniciativa diplomática que não oferecia contrapartidas econômicas e na área de segurança aos países centro-americanos. Muitos países tinham receio de uma ofensiva sandinista, como Honduras, que estava protegido com a presença de bases militares dos Estados Unidos. O governo salvadorenho continuava a receber ajuda militar com equipamentos e treinamento para combater a FMLN. Por fim, Costa Rica tinha receio de que o aumento do poder de fogo e ideológico sandinista pudesse ultrapassar a fronteira (PURCELL, 1985, p. 87-91 apud BAGLEY, 1986, p. 11).

No início de janeiro de 1985, a administração Reagan suspendeu as negociações bilaterais com a Nicarágua conduzidas no México. Esse foi um sinal claro de uma série de medidas que pressionariam o governo sandinista. Ademais, em maio, a Casa Branca anunciou a imposição de embargo econômico à Nicarágua e a Câmara dos Representantes aprovou o valor de 27 milhões de dólares em "ajuda humanitária” aos contras e não estendeu o Boland Amendment ${ }^{18}$, que foi o conjunto de atos legislativos aprovados nos anos 1980 proibindo o financiamento aos contras com a finalidade de ocasionar a deposição dos sandinistas pelos Estados Unidos (BAGLEY, 1986, p. 12).

O Grupo de Contadora também agendou uma reunião com seus integrantes para discutir o que o Grupo de Tegucigalpa estava elaborando no início de janeiro de 1985. Para isso, as Honduras, El Salvador e a Costa Rica foram convidados. Todavia, a Costa Rica afirmou que não compareceria até que a disputa sobre o asilo a ser concedido a um jovem nicaraguense fosse resolvido entre os países, com o apoio da $\mathrm{OEA}^{19}$. Em solidariedade à Costa Rica, Honduras também não confirmou presença à reunião de Contadora. Assim, os esforços de Contadora para tentar convergir os dois Grupos foram esvaziados e a reunião foi adiada para maio daquele ano. Mesmo quando o encontro ocorreu na data prevista, não houve avanços significativos (DANA SIMS; PETRASH, 1987, p. 14).

18 BROWN UNIVERSITY. Understanding the Iran-Contra affairs. "Boland Amendment". Disponível em: <http://www. brown.edu/Research/Understanding the Iran Contra Affair/n-contrasus.php $>$. Acesso em: 07 nov. 2013.

19 O jovem nicaraguense refugiou-se, pedindo asilo político na embaixada da Costa Rica em Manágua. Desrespeitando a Convenção de Viena sobre relações diplomáticas (1961), a polícia sandinista entrou na embaixada para resgatar o jovem rebelde (OJEDA GÓMEZ, 2007, p. 75).
Com o acirramento da posição da política externa dos Estados Unidos, países da América do Sul uniram-se para apoiar o Grupo de Contadora e, mais uma vez, tentaram impedir que houvesse uma solução militar para o conflito. Nos dias 2 e 8 de junho de 1985, a Argentina, o Brasil, o Peru e o Uruguai estiveram reunidos com o novo presidente peruano eleito, Alan García, e discutiram questões sobre a dívida externa e a situação da Nicarágua. Poucos dias depois, entre os dias 21 e 23 de junho, os ministros das relações exteriores Dante Caputo, da Argentina, Olavo Setúbal, do Brasil, Enrique Iglesias, do Uruguai encontraram-se em Punta del Este com a finalidade de analisar a situação na América Central e temas do continente relacionados à economia. No último dia da reunião, os chanceleres acordaram em formar um Grupo de Apoio à Contadora e formalizaram o anúncio em Lima, em 29 de julho de 1985, na posse do presidente peruano. Por esta ocasião, o Grupo de Apoio também ficou conhecido como o Grupo de Lima ${ }^{20}$. Para isolar ainda mais a postura dos Estados Unidos e sinalizar o apoio ao caminho pacífico, o Canadá também declarou apoio à iniciativa dos países latino-americanos favoráveis à Contadora (VICKERS, 1995).

A primeira reunião conjunta entre Grupo de Contadora e Grupo de Lima (Grupo dos Oito) foi realizada em Cartagena das Índias, na Colômbia, entre os dias 24 e 25 de agosto de 1985. O comunicado conjunto dos oito ministros das relações exteriores expressou:

[...] a decisão de fortalecer com ações concretas, e com uma firme unidade regional o esforço de negociações diplomáticas, que promoveu o Grupo de Contadora. Na América Central se debatem hoje questões fundamentais que afetam o desenvolvimento democrático livre e independente. Este conflito, se não encontrar uma solução pacífica e negociada, afetará a estabilidade política e social do conjunto da América Latina $^{21}$.

20 HISTORIA general de las relaciones exteriores de la Republica de la Argentina. Disponível em <http://www.argentina-rree.com/14/14-092.htm>. Acesso em: $31 \mathrm{dez} .2013$.

21 Tradução livre: “[...] la decisión de fortalecer, con acciones concretas y con una firme unidad regional el esfuerzo de negociaciones diplomáticas que ha promovido el Grupo de Contadora. En Centroamérica se debaten hoy cuestiones fundamentales que afectan su desarrollo democrático libre e independiente. Este conflicto, de no encontrar una solución pacífica y negociada, afectará la estabilidad política y social del conjunto de la América Latina”. Disponível em: <http://www.argentina-rree. com/14/14-092.htm>. Acesso em: 31 dez. 2013. 
Finalmente, em 12 de setembro de 1985, o Grupo de Contadora fez uma revisão na Ata de Paz de maneira que manteve o pedido para remover as bases militares estrangeiras da América Central; cessar a corrida armamentista na região e o tráfico de armas. Por fim, conclamou a promoção da democracia como aspecto importante para estabelecer a paz. Por outro lado, a Ata teve retrocessos, tais como: não proibiu manobras militares, versando apenas sobre a regulação da atividade. Ademais, eliminou o pedido de que os Estados Unidos parassem de dar apoio aos contras. No geral, percebe-se que o acordo retirou pontos que talvez agradassem a diplomacia estadunidense e colocaram um prazo de 45 dias para a assinatura da Ata a partir do encontro na cidade do Panamá, em 7 de outubro de 1985. Logo, a data limite seria 22 de novembro do mesmo ano.

Nesse esforço para acelerar o processo de paz, muitos pontos não atenderam a ideia original de 1984 . Sendo assim, manifestações contrárias, como as do governo sandinista, logo emergiram. A Nicarágua comunicou, em 11 de novembro de 1985, que não assinaria a Ata revisada e solicitou, já em dezembro, a suspensão das negociações de Contadora por seis meses para aguardar os resultados das eleições presidenciais na Costa Rica, Guatemala e Honduras. O objetivo era atingir novo cenário político que talvez viabilizasse um acordo possível para a região (BAGLEY, 1986, p. 12-13).

O frustrado impasse de Contadora deixou três possíveis alternativas: a escalada do conflito até o confronto armado direto, a retomada das negociações de Contadora ou a condução de novo processo negociador. A primeira opção não era a desejada pela maioria dos países: Nicarágua já acumulava perdas econômicas e a escalada do conflito deterioraria ainda mais essa situação. Ademais, essa possibilidade viabilizaria intervenção militar dos Estados Unidos e consequente derrota dos sandinistas. Em Honduras, a opção armada não garantiria vitória dos contras sem apoio militar (leia-se intervenção) dos Estados Unidos, deixando o território hondurenho como base de operações e vulnerável a ataques. Por sua vez, em El Salvador, tanto exército quanto FMLN eram capazes de resistir um ao outro, mas não eram plenamente capazes de suprimir o oponente sem ajuda externa. Por fim, na Guatemala, o exército perseguiu o objetivo de aniquilar a URNG, com a ajuda externa dos Estados
Unidos $^{22}$. Por isso, o diálogo era a alternativa mais sensata para encerrar o término de hostilidades e parar com tantas mortes de guatemaltecos ao longo da guerra civil (1960-1996) (HARTO DE VERA, 1991, p. 184-6). Nessa conjuntura, a maioria dos países centro-americanos optou pela continuidade do diálogo, o que seria encaminhado no ano seguinte, mas em outro formato.

Pode-se dizer que o problema de Contadora foi a insistência em negociar itens de extrema divergência de interesses entre Nicarágua e Estados Unidos. A iniciativa multilateral enfraqueceu por diferentes motivos: Venezuela se opôs a intransigência do governo sandinista, a Colômbia necessitou de ajuda dos Estados Unidos para negociar a dívida no Fundo Monetário Internacional (FMI), logo, não teve força política para negociar um acordo mais plausível para contemplar a Nicarágua. O México, por sua vez, enfrentou contestação interna quanto à condução de Contadora, pois os setores conservadores mexicanos acreditavam que o México conduzia o processo de paz favorecendo a Nicarágua. Independente das contestações em âmbito doméstico, o México estava vulnerável financeiramente e devia ao FMI e ao Banco Mundial, necessitando futuramente aproximar-se dos Estados Unidos para negociar o débito. No início de dezembro de 1985, a Venezuela, a Colômbia e o Panamá desistiram da Ata revisada de Contadora ${ }^{23}$, não comunicaram essa desistência ao México e passaram a comparecer aos encontros de Tegucigalpa (BAGLEY, 1986, p. 14).

Ainda que o Grupo tivesse diminuído, os países do Grupo de Contadora e Grupo de Lima tomaram fôlego para reabrir negociações no início de janeiro de 1986. Nos dias 11 e 12 desse mês, os países reuniram-se em Caraballeda, Venezuela, e produziram uma declaração

22 Por três décadas, os Estados Unidos apoiaram o exército guatemalteco para suprimir as guerrilhas, como se pode depreender das palavras de Grandin (2004, p. 19): "os Estados Unidos continuaram suprindo as forças de segurança guatemaltecas de equipamento, treinamento e financiamento, mesmo quando a repressão se tornou feroz. As práticas ensaiadas na Guatemala - como as operações secretas de desestabilização e os esquadrões de morte dirigidos por agências de inteligência profissionalizadas - propagaram-se por toda a região nas décadas subsequentes. Por mais que lamentasse o Vietnã como um fracasso, Washington seguiu considerando a Guatemala um sucesso. Na década de 1980, a escalada final do conflito entre as superpotências transformou o país, assim como a Nicarágua e El Salvador, num dos últimos campos de extermínio da guerra fria".

23 Assinaturas ou desistências sobre a Ata deveriam ser feitas junto a Assembleia Geral das Nações Unidas. 
comprometendo-se com as negociações de paz e pediram para que a administração Reagan cessasse apoio aos contras e retomassem as negociações com a Nicarágua (BAGLEY, 1986, p. 15). A ideia era justamente não deixar a iniciativa diplomática esmorecer, abrindo caminho para a escalada do conflito e para a solução armada dos Estados Unidos. Assim, era uma questão de tentar manter um possível desfecho pacífico latino-americano e, acima de tudo, impedir que o conflito se aprofundasse ainda mais na esfera leste-oeste.

Em fevereiro de 1986, os oito ministros das relações exteriores do Grupo de Contadora e do Grupo de Lima resolveram realizar uma visita ao secretário do Departamento de Estado, George P. Schultz, para pedir o fim do apoio aos contras. Poucos dias após a visita, o governo dos Estados Unidos afirmou que renovaria o apoio aos contras (BAGLEY, 1986, p. 16), ignorando o gesto da iniciativa multilateral do Grupo dos Oito.

O Grupo de Contadora retomou negociações em abril sob liderança do México e com a participação dos países centro-americanos. A ideia era pressionar pelo fim do apoio aos contras e isso foi contestado pelo Grupo de Tegucigalpa. Mais uma vez a insistência era válida, mas ingênua dentro daquele contexto.

No Legislativo dos Estados Unidos, principalmente no Senado, o grande problema era a divisão e desconfiança dos senadores quanto a melhor decisão a contemplar. Apoiar Contadora era a melhor alternativa, mas os conservadores temiam que, uma vez comprometidos em parar de enviar recursos aos contras tal como os sandinistas queriam, isso pudesse ser uma trapaça do governo sandinista para ganhar força e incentivar revoluções em outros países da região. A falta de coesão interna era grande entre Casa Branca, Senado, Departamento de Estado e Departamento de Defesa. Aproveitando-se do cenário político institucional conturbado dos Estados Unidos, os cinco países da América Central reuniram-se em Esquipulas, na Guatemala, nos dias 25 e 26 de maio. Todos os presidentes pediram para que até 6 de junho de 1986, a Nicarágua assinasse a Ata de Paz de Contadora (BAGLEY, 1986, p. 17-18). Quando esse encontro aconteceu, os integrantes de Contadora resolveram continuar trabalhando para um acordo possível e, desta vez, não estabeleceram um prazo para a assinatura ou versão final (DANA SIMS; PETRASH, 1987, p. 24).

Quanto aos Estados Unidos, um dos maiores interessados pela solução rápida (militar), o arrefecimento da insistência na alternativa do confronto armado ocorreu a partir do momento em que o governo Reagan foi exposto a constrangimentos após a divulgação na imprensa, em novembro de 1986, sobre o fornecimento secreto de armas ao Irã na guerra contra o Iraque (1980-1988), na qual os Estados Unidos eram aliados políticos deste. Os recursos com a venda de armas ao Irã foram usados para financiar os contras ${ }^{24}$. O desfecho do escândalo resultou na abertura da apuração dos fatos que envolveu funcionários do Conselho Nacional de Segurança dos Estados Unidos, acusados de corrupção em 1986. Dessa maneira, a alternativa militar foi protelada politicamente pelos Estados Unidos e a política externa de Reagan para a Nicarágua foi gradativamente perdendo força no cenário doméstico (ARNSON, 1989, p. 225-6), o que facilitou a retomada de iniciativas diplomáticas pelos atores regionais centro-americanos.

A hipótese de retomada das negociações de Contadora não era oportuna por já ter apresentado previamente sinais de esgotamento após impasses em 1983 e 1986. Os motivos para que não houvesse assinatura eram diversos entre os países. A começar pela Nicarágua, pois perderia em torno de 800 militares cubanos propícios a treinarem militares sandinistas, além do fornecimentos de armas de combate. El Salvador perderia os 54 militares estadunidenses que auxiliavam o exército contra os guerrilheiros salvadorenhos. Honduras perderia os 800 militares dos Estados Unidos para operações conjuntas, que os protegiam contra uma possível contraofensiva sandinista, e da mesma maneira pensava a Costa Rica quanto à preservação do próprio território. Por fim, os Estados Unidos apenas acreditavam na solução que viabilizasse a transição de regime político na Nicarágua e a desmobilização da FSLN (DANA SIMS; PETRASH, 1987, p. 24).

Qualquer insistência na assinatura da Ata de Paz de Contadora com a conjuntura e interesses expostos desagregaria ainda mais os países. Dessa maneira, o encaminhamento de novo processo negociador foi a melhor escolha para propor outra solução. Preferencialmente, com nova liderança. Essa alternativa também interessava aos Estados Unidos, pois seria oportuno colocar uma nova proposta que defendesse seus interesses por meio de

24 BROWN UNIVERSITY. Understanding the Iran-Contra Affairs. Disponível em: <http://www.brown.edu/Research/ Understanding_the_Iran_Contra_Affair/>. Acesso em: 07 nov. 2013. 
um novo e "neutro" ator regional. Resumindo, nas palavras de López Hernández (1993, p. 94), o Grupo de Contadora e o Grupo de Apoio à Contadora reuniram-se em 6 de junho de 1986, sabendo que não haveria assinatura da Ata de Paz. Os integrantes de Contadora anunciaram que as negociações seriam transferidas para Esquipulas, pois já haviam acumulado experiência prévia em 25 de maio de 1986, quando ocorreu a primeira reunião de cúpula de presidentes centro-americanos, e caberia a esses países conduzirem novo processo de paz para a região.

\section{Os acordos de Esquipulas e as cúpulas pre- sidenciais centro-americanas}

A Declaração de Guatemala, assinada em 25 de maio de 1986, foi o resultado da primeira reunião entre países centro-americanos para iniciar o entendimento que pudesse gerar um novo acordo de paz. Dada a continuidade das negociações sobre essa primeira versão, a declaração assinada na Guatemala ficou conhecida como Esquipulas $\mathrm{I}^{25}$.

Influenciada pelo processo anterior, há pontos da Ata de Paz de Contadora que remanesceram em Esquipulas I, como a busca por encontrar soluções para pendências quanto as manobras militares na região, o controle de armamentos e a verificação do cumprimento dos acordos. Resume-se de Esquipulas I que houve consenso dos presentes quanto a importância das negociações continuarem nas mãos dos presidentes. Logo, o formato de cúpulas presidenciais foi mantido para proporcionar o essencial diálogo, confiança mútua e entendimento direto.

Entre as inovações que a declaração de Esquipulas I trouxe, situa-se a sugestão para criar o parlamento centro-americano como possível forma constante de diálogo entre os países ${ }^{26}$. É interessante observar que, a partir do

25 Esquipulas I está disponível em:

<http://www.parlacen.int/InformaciónGeneral/MarcoPolíticoyJurídico/EsquipulasI.aspx>. Acesso em: 24 fev. 2013. As sucessivas versões de Esquipulas I são reconhecidas pela numeração progressiva (Esquipulas I, II, III...) ou identificadas como "declaração de", acrescida do nome da cidade onde as reuniões foram celebradas.

26 O PARLACEN passou a funcionar a partir da primeira Assembleia Plenária em 28 de outubro de 1991, tendo como sede a Cidade de Guatemala. Disponível em: <http://www. parlacen.int/InformaciónGeneral/HistoriadelParlamento. aspx>. Acesso em: 20 out. 2013. momento que o Parlamento Centro-americano (PARLACEN) constou na redação, pressupunha-se que a continuidade das relações entre os países previa a eleição de parlamentares que o comporiam. Logo, este é um indício do que se esperava dos países da América Central: a manutenção de regimes políticos democráticos. No caso da Nicarágua, sugere-se que estava implícita a futura transição. Pode-se inferir que tal intenção estava anunciada nesse trecho "que a paz na América Central somente possa ser fruto de um autêntico processo democrático pluralista e participativo" 27.

Outro apontamento importante é que os encontros iniciados na Guatemala surgiram esperançosos com a nova configuração política em 1986, oriunda da posse de novos presidentes: na Guatemala, com Marco Vinicio Cerezo Arévalo, em 14 de janeiro de 1986 - presidente que convidou os demais para as negociações em Esquipulas -; em Honduras, com José Simón Azcona del Hoyo, em 27 de janeiro, e na Costa Rica, com Óscar Arias Sánchez, em 8 de maio.

A preparação de um plano para superar a crise na América Central, já era uma das promessas do candidato Arias (BRENES, 1985). Quando presidente, a ideia foi posta em prática e uma série de reuniões aconteceu para chegar à melhor alternativa. Sobre a preparação do Plano Arias, Harto de Vera (1991, p. 190) argumentou:

O presidente Óscar Arias realizou uma visita aos Estados Unidos em dezembro de 1986. Durante esses contatos, estabeleceu-se a convergência básica entre as visões de Costa Rica e Estados Unidos no sentido de responsabilizar ao regime sandinista como o principal culpado da crise na América Central. A identidade de critérios foi praticamente total e o assunto do questionamento de Costa Rica para o apoio norte-americano para a contrarrevolução foi minimizado. Nesta ocasião, recebeu a sugestão do vice-presidente Bush de formular um plano de paz para a América Central. Ademais, no início de janeiro, o ministro das relações exteriores da Costa Rica, Rodrigo Madrigal, manteve uma entrevista com Philip Habib e com Elliot Abrams com o objetivo de analisar uma nova proposta de pacificação para a América Central de cunho norte-americano ${ }^{28}$.

27 Tradução livre: "Que la paz en América Central sólo puede ser fruto de un auténtico proceso democrático pluralista y participativo" (Esquipulas I).

28 Tradução livre: "Durante estos contactos, se estableció la convergencia básica entre las visiones de Costa Rica y de los Estados Unidos en el sentido de responsabilizar al regimen sandinista como el principal culpable de la crisis en Centro- 
Em 15 fevereiro de 1987, o presidente da Costa Rica, Óscar Arias, reuniu os presidentes de Honduras, Guatemala e El Salvador, em San José, com a finalidade de chegarem a um entendimento a ser apresentado à Nicarágua, que não fora convidada para o encontro (ROJAS ARAVENA, 1989a, p. 3). O governo sandinista foi comunicado sobre a proposta de San José e deveria manifestar-se sobre a notificação em 15 dias. O Plano Arias ${ }^{29}$ buscou (1) conceitos básicos de consenso na área política e de segurança, (2) percepções distintas para a solução dos diversos problemas, (3) evitar a escalada do conflito, (4) vincular em uma mesma proposta paz, democracia e desenvolvimento, com prazos específicos e preestabelecidos (ROJAS ARAVENA, 1989b, p. 232). Em termos gerais, o encontro gerou o documento "Um tempo para a paz", no qual se defende ser a democracia muito importante para a solução da crise:

\begin{abstract}
A paz que reclama sua vez, também reclama o fortalecimento da democracia em todas as nações da América. Assim, abrir-se-ão as portas para a liberdade e a democracia, em que os homens poderão eleger livre e periodicamente seus governantes, prevalecerá o pluralismo político, o diálogo e a manifestação das ideias, a luta armada somente pode ser interpretada como o desejo de estabelecer uma nova ditadura: não se trata de lutas libertárias, senão de um grupo de fanáticos que pretendem impor pela força o pensamento de uma minoria qualquer que seja seu teor ideológico ${ }^{30}$.
\end{abstract}

américa. La identidad de criterios fue prácticamente total y el asunto del cuestionamiento de Costa Rica hacia el apoyo norteamericano a la contrarrevolución es minimizado. En esta ocasión, recibió la sugerencia del vicepresidente Bush de formular una plan de paz para Centroamérica. Asimismo a comienzos de Enero el ministro de Asuntos exteriores de Costa Rica Rodrigo Madrigal sostuvo una entrevista con Philib Habib y con Elliot Abrams con el objeto de analizar una nueva propuesta de pacificación para Centroamérica de cuño norteamericano."

29 O Plano Arias foi aprovado pelo Senado dos Estados Unidos em 12 de março de 1987, mesmo com a resistência dos conservadores republicanos (ANNUNZIATA, 1987, p. 505).

30 Tradução livre: "La paz que reclama su hora, también reclama el robustecimiento de la democracia en todas las naciones de América. Ahí donde se han abierto las puertas de la libertad y la democracia, donde los hombres pueden elegir libre y periódicamente a sus gobernantes, donde prevalecen el pluralismo político, el diálogo y la expedita manifestación de las ideas, la lucha armada sólo puede interpretarse como el deseo de establecer una nueva dictadura: no se trata de luchas libertarias, sino de pugnas de fanáticos que pretenden imponer por la fuerza el pensamiento de una minoría, cualquiera que sea su signo ideológico". Disponível em: <http:// www.inep.org/Textos/7CRumbo/1987HPD.html>. Acesso em: 10 dez. 2013.
Além da ênfase no retorno de regimes políticos democráticos, existe clara condenação da luta armada vista como forma de imposição da vontade de uma minoria. Harto de Vera (1991, p. 194-5) pontuou que, quando esse documento tornou-se conhecido pela Nicarágua, o governo foi totalmente desfavorável ao texto. Ainda assim, "Um tempo para a paz" usou palavras mais amenas do que a versão preliminar, profundamente antisandinista. As reformulações e a inclusão da Nicarágua nesse processo de paz aconteceu sob manifestação da Guatemala que pretendia continuar apenas se os cinco países do istmo pudessem participar. Com temor de que as negociações fossem esvaziadas, a posição inicial foi revista e o teor dos diálogos foi de menor condenação ao sandinismo e maior incentivo para a transição de regime na Nicarágua. Rapidamente a manifestação dos Estados Unidos foi de descontentamento pelo fato das negociações terem perdido o tom condenatório. Contudo, à medida que o processo de paz avançava, foi possível obter flexibilização da administração Reagan quanto a esse aspecto do processo de paz.

Ao final das negociações de "Uma hora para a paz", os cinco países acordaram sobre o "Procedimento para estabelecer a paz firme e duradoura na América Central". Esse compromisso foi importante para estabelecer metas a serem melhor trabalhadas internamente pelos países para que fosse possível amadurecer opiniões e alcançar um acordo benéfico para a região. Assim, nesse primeiro esboço, os objetivos consignados podem ser resumidos:

Quadro 1: Procedimento para estabelecer a paz firme e
duradoura na América Central
OBJETIVOS:
1. $\quad$ reconciliação nacional (anistia e diálogo)
2. cessar fogo
3. democratização
4. eleições livres
5. suspensão de ajuda militar (oriunda de governos estrangeiros)
6. não uso do território para agredir a outros Estados
7. $\quad$ redução de armamentos
8. $\quad$ supervisão nacional e internacional:
a) comitê de acompanhamento (ONU, OEA, Grupo de Contadora e
10. Democracia e liberdade para a paz e para o desenvolvimento
avaliação de programas para a paz
Grupo de Lima)

Fonte: (ROJAS ARAVENA, 1989b, p. 232)

Percebe-se que esse primeiro esboço trouxe as- 
pectos importantes e propostas concretas quanto ao que era imprescindível para alcançar a paz na região. Desde o primeiro acordo de paz, proposto em fevereiro (Esquipulas I), para o segundo, de agosto de 1987 (Esquipulas II), diversas reuniões e posições divergentes foram tomadas pelos envolvidos na questão. O compromisso "Uma hora para a paz" foi ainda mais discutido, adaptado e as modificações foram incluídas em Esquipulas $\mathrm{II}^{31}$.

Óscar Arias reuniu-se com todos os presidentes em diferentes momentos, solicitou e realizou encontros com os grupos que formaram o Grupo de Contadora e o Grupo de Apoio à Contadora, bem como teve encontros com os secretários-gerais da ONU e da OEA. Ao passo que essas reuniões aconteciam, também os chanceleres da América Central buscavam avaliar o posicionamento dos atores políticos no intuito de convergir propostas. Destaca-se que não somente existiu o empenho de Óscar Arias, como também do presidente guatemalteco junto aos presidentes de El Salvador e Honduras para que a cúpula de agosto não fosse esvaziada (HARTO DE VERA, 1991, p. 197). A relutância desses países era de certa maneira em solidariedade quanto as críticas que os Estados Unidos fizeram às adaptações no Plano Arias, distanciando-se do que o presidente costa-riquenho discutiu em Washington, em dezembro de 1986. No entanto, o presidente da Guatemala conseguiu convencer os demais que certa flexibilização foi importante para manter a Nicarágua no processo e, com isso, além de manter um diálogo maduro, os países conseguiram juntos propor um acordo que solucionasse a crise regional.

Por fim, os encontros em Esquipulas, nos dias 6 e 7 de agosto de 1987, alcançaram nova versão do acordo de paz, com metas para os processos de reconciliação nacional, desmobilização de grupos armados e guerrilhas e encaminhamento de eleições. Os pontos mais importantes de Esquipulas II estão a seguir consignados:

31 Esquipulas II está disponível em: <http://www.parlacen.int/ InformaciónGeneral/MarcoPolíticoyJurídico/EsquipulasII. aspx>. Acesso em: 31 out. 2013.
Quadro 2: Esquipulas II (7 de agosto de 1987)

1. reconciliação nacional

a) diálogo

b) anistia

c) comissões nacionais de reconciliação

2. condenação e incentivo ao fim das hostilidades

3. democratização

4. eleiçōes livres

5. interromper ajuda as forças irregulares ou aos movimentos insurrecionais

6. não fazer uso do território para agredir outros Estados

7. realizar negociaçōes em matéria de segurança, verificação, controle e limitação de armamentos

8. refugiados

9. cooperação e democracia, liberdade para a paz e o desenvolvimento

10. verificação e acompanhamento internacional

a) comissão internacional de verificação

b) respaldo para mecanismos de reconciliação

11. Calendário de execução de compromissos

Fonte: (ROJAS ARAVENA, 1989b, p. 233)

Apesar de todo o esforço dos Estados Unidos para que se chegasse ao final da cúpula sem uma decisão ou compromissos, os cinco presidentes ignoraram as diferentes propostas apresentadas ${ }^{32}$ e discutiram apenas a evolução do que foi iniciado no ano anterior (Esquipulas I). Além dos pontos que foram acrescidos, os prazos para o cumprimento foram melhor adaptados ao que cada país poderia viabilizar.

32 As quatro propostas eram duas já existentes, como o Plano Arias, a Paz de Contadora, um anteprojeto proposto por Honduras que deveria se configurar como nova proposta, e o Plano de Reagan-Wright (HARTO DE VERA, 1991, p. 200). O Plano Reagan-Wright foi apresentado pelo Secretário de Departamento de Estado em 5 de agosto de1987. A proposta foi feita em momento simultâneo ao contexto do escândalo Irã-contras e com a finalidade de obter concessões do governo sandinista em troca de descartar a alternativa de intervenção militar dos Estados Unidos na Nicarágua (ARNSON, 1989 , p. 221). Os principais pontos da proposta elaborada em parceria pela Casa Branca e o porta-voz da Câmara dos Representantes, o democrata texano Jim Wright, eram: propor um cessar fogo sob supervisão da OEA ou grupo de observadores internacionais e, uma vez consolidada essa meta, os Estados Unidos suspenderiam ajuda militar aos contras, desde que a Nicarágua deixasse de receber ajuda militar da União Soviética, Cuba e do bloco socialista. Ademais, os Estados Unidos solicitaram a restituição dos direitos civis pelo governo sandinista; ter uma comissão eleitoral multipartidária e independente em 60 dias para celebrar eleições; os Estados Unidos suspenderiam as manobras militares nas Honduras, uma vez estabelecido o cessar fogo; os Estados Unidos propunham um acordo para a redução dos exércitos centro-americanos e a presença militar estrangeira que desse suporte as guerrilhas; os Estados Unidos sugeriram um programa de desmobilização de forças militares, sendo o governo sandinista responsável pelo processo de reconciliação nacional e anistia; e outros assuntos pertinentes a facilitação de cooperação econômica para o país quando a Nicarágua tivesse um governo democrático (SORTO, 2001, p. 204). 
Destaca-se que a celebração de Esquipulas II aconteceu em um momento de desgaste da administração Reagan com os países do istmo, pois os Estados Unidos haviam sido condenados pela Corte Internacional de Justiça quanto a questão da Nicarágua ${ }^{33}$, o escândalo Irã-contras desmoralizou a política externa para a América Central e existia evidente descrédito na continuidade do discurso da vitória militar, pois nem mesmo essa alternativa permanecia atraente ao governo estadunidense $\mathrm{e}^{34}$ (SORTO, 2001, p. 205).

Um passo importante, que fez Esquipulas II avançar enquanto proposta de paz, foi o foco na dimensão interna dos conflitos a ser cuidada pelos países. Assim como discutiu Rojas Aravena (1994, p. 12):

Esquipulas II mudou o foco de atenção e o peso foi posto em resolver os conflitos domésticos e alcançar a reconciliação nacional mais do que em tentar resolver as ameaças à segurança externa. Na percepção centro-americana, a principal ameaça centrava-se no ataque aos sistemas políticos constituídos, independente de sua orientação. Por isso, Esquipulas II buscou atuar principalmente no plano político na primeira etapa, antes de avançar para outras áreas. A construção de legitimidade supôs o estabelecimento de níveis mínimos de confiança recíproca, tanto nacional como internacionalmente ${ }^{35}$.

Pode-se apresentar as fases de implementação de Esquipulas II na seguinte divisão: (1) a primeira fase, os 90 dias iniciais após a assinatura; (2) os 60 dias seguintes até a reunião entre os presidentes, em janeiro de 1988;

33 Em 9 de abril de 1984, a Nicarágua entrou com uma ação contra os Estados Unidos na Corte Internacional de Justiça (CI)), principal órgão judiciário da ONU, condenando as atividades militares e paramilitares contra o seu território. A CIJ determinou, em 27 de junho de 1986, que os Estados Unidos cessassem a obstrução dos portos nicaraguenses e colocação de minas terrestres; bem como interrompessem as atividades militares e paramilitares contra a Nicarágua (SORTO, 1995).

34 O presidente Ronald Reagan havia sido advertido pelo Pentágono que uma intervenção militar na Nicarágua seria dispendiosa, longa e com muitas baixas militares para os Estados Unidos (GLEISEJES, 1991 apud SORTO, 2001, p. 202).

35 Tradução livre: "Esquipulas II cambió el foco de la atención y el peso fue puesto en resolver los conflictos domésticos y alcanzar la reconciliación nacional, más que intentar resolver las amenazas a la seguridad externa. En la percepción centroamericana la principal amenaza se centraba en el ataque a los sistemas políticos constituídos, independientemente de su orientación. Por ello, Esquipulas II buscó actuar principalmente en el plano político en una primera etapa, antes de avanzar hacia otras áreas. La construcción de legitimidade supuso el establecimiento de niveles mínimos de confianza recíproca, tanto a nível nacional como internacional”.
(3) a reunião de cúpula presidencial em Alajuela (Costa Rica), em 15 e 16 de janeiro de 1988 até o estancamento; e, por fim, (4) a quarta etapa, em novembro de 1988, com a reativação do processo até a cúpula presidencial em El Salvador, em 15 de fevereiro de 1989 (ROJAS ARAVENA, 1994, p. 238).

A rápida primeira etapa prosseguiu com avanços em escala interna, com a criação de Comissões Nacionais de Reconciliação (CNR), a criação de uma Comissão Internacional de Verificação e Acompanhamento (CIVA) ${ }^{36}$ e uma Comissão Executiva (CE). Sobre as CNR, Aguilera Peralta (1988, p.135) identificou que a CNR da Guatemala foi formada em 9 de setembro de 1987; a de El Salvador em 1 de setembro de 1987; e a da Nicarágua em 1 de agosto de 1987. Todos os países que tiveram guerras civis.

Quanto à disposição de Esquipulas II sobre a anistia, Aguilera Peralta (1988, p. 135) informou que foi aprovado na Guatemala um decreto legislativo, em 26 de outubro de 1987; em El Salvador, um dia depois da aprovação na Guatemala; e, na Nicarágua, o Poder Executivo enviou um projeto de lei sobre anistia à Assembleia Nacional que entrou em vigor quando a Comissão Internacional de Verificação e Acompanhamento passou a funcionar, em 1989.

Quanto ao ponto 2 (cessar fogo) do acordo de Esquipulas II, os insurgentes guatemaltecos declararam cessar fogo unilateral entre os dias 3 e 7 de outubro de 1987, em El Salvador, tanto governo quanto guerrilha anunciaram cessar fogo entre novembro e dezembro de 1987, e na Nicarágua, o governo decretou cessar fogo unilateral de trinta dias (entre 7 de outubro e 7 de novembro de 1987). Em datas próximas ao cessar fogo, em cada país, também ocorreu a formalização do diálogo entre governo e oposição armada, conforme o ponto 1 de Esquipulas II (AGUILERA PERALTA, 1988, p. 137).

À euforia de implementação da primeira fase foi contraposta a morosidade da etapa seguinte, a de 60 dias, de novembro de 1987 a janeiro de 1988. Grande parte dos problemas foram oriundos de entraves para os trabalhos da CIVA em campo (CANDANEDO, 1988). Surpresas na verificação também puderam ser identificadas. Por exem-

36 A CIVA foi composta pelos ministros das relações exteriores do Grupo de Contadora e Grupo de Lima, em parceria com os secretários-gerais da ONU e da OEA. A CIVA deveria atuar junto com os ministros das relações exteriores dos países centro-americanos para o cumprimento de Esquipulas II (ROJAS ARAVENA, 1989a, p. 19). 
plo, em Honduras, não deveriam existir contras e numa visita da CIVA, um grupo foi localizado. Nesse aspecto, o governo hondurenho justificou que era impossível banir todos os grupos do território por razões humanitárias (HARTO DE VERA, 1991, p. 205-206).

Outro ponto em que houve divergência do que ficara acordado anteriormente para o que foi observado pela CIVA, dizia respeito às informações sobre a Costa Rica. Constou no relatório da CIVA, produzido em 12 de janeiro no Panamá, o caráter sólido e democrático do país, além da falta de necessidade de anistia por não haver presos políticos. Todavia, esse registro foi apontado nos primeiros encontros para executar o Plano Arias, quando o sistema político costa-riquenho foi caracterizado como fortemente bipartidarista e, desse modo, criava dificuldades para a participação popular (HARTO DE VERA, 1991, p. 206-207).

Com certa dificuldade de atuação, a CIVA necessitou de pessoal especializado para a verificação de Esquipulas II nos campos político e de segurança. Alemanha, Canadá e Espanha propuseram dar esse auxílio e posteriormente foram países que participaram da missão de observação militar da ONU para a América Central, a ONUCA. Assim, destacando esse ponto, Rojas Aravena (1989a, p. 19) argumentou:

As tarefas de verificação em qualquer de seus âmbitos político ou de segurança [...] requerem conhecimentos técnicos, equipes e pessoal capacitado. A América Central tem grandes carências nestes campos. Por isso, solicitou a participação de Alemanha, Canadá e Espanha para a realização destas funções ${ }^{37}$.

Em termos gerais, as críticas ainda estavam no fato de que os Estados Unidos continuavam a prestar auxílio aos contras. Assim, havia dificuldade de implementar Esquipulas II seguindo os conceitos de "simultaneidade" e "reciprocidade", tal como foi acordado. Acima de tudo, existiam divergências e dificuldades para executar o compromisso entre os países quanto às necessidades e entraves internos (HARTO DE VERA, 1991, p. 207-208). Posteriormente, na segunda fase de negociação, esses conceitos de "simetria" e "simultaneidade" de Esquipulas II foram abandonados (ROJAS ARAVENA, 1989a, p. 21).

Dessa maneira, a III cúpula presidencial realiza-

37 Tradução livre: "Las tareas de verificación en cualquiera de sus ámbitos político o de seguridad [...] requiere conocimientos técnicos, equipos y personal capacitado. Centroamérica tiene grandes carencias en estos campos, por ello solicitó la participación de Alemania, Canadá y España para la realización de estas funciones". da em San José (Costa Rica), nos dias 15 e 16 de janeiro de 1988, deveria possibilitar avanços. Na declaração presidencial, Esquipulas III ou Declaração de Alajuela ${ }^{38}$, assinada em 16 de janeiro de 1988, os presidentes fizeram reservas a alguns apontamentos críticos do relatório CIVA e reafirmaram que, mesmo com dificuldades, promoveriam os compromissos assumidos em Esquipulas II:

Por não ter satisfeito inteiramente o cumprimento dos compromissos de Esquipulas II, se comprometem a satisfazer obrigações incondicionais e unilaterais que obrigam aos governos a um cumprimento total [...]. Sendo assim, estão o diálogo, as conversas para viabilizar o cessar fogo, a anistia geral e, sobretudo, a democratização que necessariamente inclui o levantamento do Estado de exceção, a total liberdade de imprensa, o pluralismo político e o funcionamento de tribunais especiais. Os compromissos anunciados que não foram cumpridos deverão ser cumpridos imediatamente de forma pública e evidente ${ }^{39}$.

Outro aspecto importante que aparece na declaração é a referência feita à Comissão Executiva, composta pelos ministros das relações exteriores dos signatários de Esquipulas II. A CE estava responsável por acompanhar a implementação dos compromissos da Declaração de Guatemala e coordenar as cúpulas presidenciais. As atribuições da CE não implicavam necessariamente cobrança e pressão para avanços, pois os próprios países que a compunham eram também os responsáveis pelo seu cumprimento. Assim, a responsabilidade de verificação ficou relativamente prejudicada. A CE foi um órgão de caráter executivo e estava abaixo das cúpulas presidenciais e acima das Comissões Nacionais de Reconciliação (ROJAS ARAVENA, 1989a, p. 18-19).

Diversas dificuldades, entre essas expostas, apenas sinalizaram para o estancamento que o processo de paz

38 Declaração de Alajuela está disponível em: <http://www.minex.gob.gt/MDAA/DATA/MDAA/ 201011081130043771988-1-16IIIREUNIONORDINARIA (CostaRica).pdf>. Acesso em: 28 out. 2013.

39 Declaração de Alajuela. Tradução livre: "Por no estar satisfecho enteramente el cumplimiento de los compromisos de Esquipulas II, se comprometen a satisfacer obligaciones incondicionales y unilaterales que obligan a los gobiernos a un cumplimiento total [...]. Dentro de estas, se encuentran el diálogo, las conversaciones para la concertación del cese de fuego, la amnistía general y, sobre todo, la democratización, que necesariamente incluye el levantamiento del Estado de Excepción, la libertad de prensa total, el pluralismo político y el no funcionamiento de tribunales especiales. Los compromisos enunciados que no se han cumplido por los gobiernos, deberán ser cumplidos inmediatamente en forma pública y evidente." 
teria ao longo de 1988, o que configurou a terceira fase do processo de paz de Esquipulas II. Muitos dos problemas foram oriundos de adversidades políticas internas: a Nicarágua seguiu em diálogo nacional entre sandinistas e outros grupos políticos; nas eleições de março, em El Salvador, os democratas-cristãos perderam para a ARENA, sendo que esse partido e o presidente Alfredo Cristiani eram muito pouco propensos a negociar os avanços do processo de Esquipulas II; na Costa Rica, existiram problemas de ordem econômica derivados da relativa autonomia que o país assumiu nas negociações centro-americanas, em detrimento das orientações da administração Reagan. Ademais, a imprensa do país passou a criticar o governo de Óscar Arias por dar muita ênfase à política exterior, colocando em segundo plano questões internas. Por fim, o presidente guatemalteco teve que superar a tentativa de um golpe de Estado em maio (HARTO DE VERA, 1991, p. 211-212).

Não se pode esquecer, também, que antes da assinatura da Declaração de Alajuela, o governo estadunidense mobilizou-se, tal como fez perante a iniciativa de Contadora, para impedir o avanço no processo de paz centro-americano. Nas palavras de Sorto (2001, p. 210), entre os dias 5 e 9 de janeiro, um grupo de funcionários do governos dos Estados Unidos visitou a Guatemala, El Salvador, as Honduras e a Costa Rica. Colin Powell, Assessor de Segurança Nacional, Elliot Abrams, Subsecretário de Estado Adjunto para Assuntos Interamericanos, e Morris Busby, Enviado Especial para a América Central, alertaram os representantes dos países do istmo sobre os danos do possível não-cumprimento de Esquipulas II por parte da Nicarágua (WICKER, 1988). Uma vez que essa investida fracassou, depois da assinatura em Alajuela, a administração Reagan trabalhou com os principais aliados, El Salvador e Honduras, com a finalidade de preparar as condições para uma guerra regional não utilizando os contras, e sim os exércitos desses países (OPAZO BERNALES, 1990, p. 262 apud SORTO, 2001, p. 213). Contudo, Guatemala e Costa Rica permaneceram firmes nas negociações para a continuidade da implementação de Esquipulas II e o plano de Reagan não perseverou.

O estancamento das negociações entre os países centro-americanos favoreceu novamente para que a administração Reagan tentasse desmobilizar a iniciativa Arias por meio de reuniões bilaterais e aguardando retomar a Comunidade Democrática Centro-americana e o Foro Pro-Paz e Democracia. Acima de tudo, o secretário de Estado buscou novamente isolar a Nicarágua mantendo conversas bilaterais. No entanto, a Guatemala e a Costa Rica, aqueles que melhor articularam a mediação de Esquipulas II, negaram-se a assinar qualquer acordo bilateral que punisse a Nicarágua. Ao observar a manobra diplomática dos Estados Unidos, muitos países latino-americanos voltaram a conversar com os representantes dos países centro-americanos para impedir um retrocesso das negociações. Essa manobra diplomática fez com que os países do istmo voltassem a pressionar a Nicarágua para que fizesse a transição para a democracia (HARTO DE VERA, 1991, p. 212-3). Rojas Aravena (1989a, p. 20) destacou que os avanços e retrocessos do processo em geral estavam associados com a incorporação de legitimidade democrática na Nicarágua.

\section{Demais Declarações Presidenciais e o en- volvimento da ONU e da OEA}

A pressão de diversos países auxiliou para que as negociações retomassem vigorosamente na reunião de cúpula presidencial seguinte, que aconteceu em Costa del Sol, El Salvador, entre os dias 13 e 14 de fevereiro de 1989. A partir dessa reunião, começou a quarta fase das negociações que compreendeu sucessivos encontros ${ }^{40}$.

O mais significativo da Declaração de Costa del $\mathrm{Sol}^{41}$ foi o compromisso da Nicarágua com eleições para 25 de fevereiro de 1990, sob monitoração de observadores internacionais da ONU e da OEA. Assim, a agenda que a Nicarágua pretendia executar contemplou: reformas das leis eleitorais; preparação, organização e mobilização de partidos políticos; formar um Conselho Eleitoral; e assegurar o funcionamento plural dos meios de comunicação para a realização das eleições. Além desse importante aspecto político, outros pontos ligados ao desenvolvimento e aos refugiados compuseram a pauta de Esquipulas IV.

40 Esquipulas IV, ou Declaração de Costa del Sol; Esquipulas V, ou Declaração de Tela (Honduras), em 7 de agosto de 1989; Esquipulas VI, ou Declaração de San Isidro de Coronado (Costa Rica), em 12 de dezembro de 1989; Esquipulas VII, ou Declaração de Montelimar (Nicarágua), em 3 de abril de 1990; Esquipulas VIII, ou Declaração de Antigua (Guatemala), em 17 de junho de 1990; Esquipulas IX, ou Declaração de Puntarenas (Costa Rica), em 17 de dezembro de 1990.

${ }^{41}$ Esquipulas V está disponível em: <http://biblioteca.icap. ac.cr/BLIVI/RCAP/22_23/art9_22_23.pdf>. Acesso em: 11 nov. 2013. 
Esse foi um fato expressivo e que influenciou os outros países a contribuir com o processo. Esquipulas IV estipulou para maio do mesmo ano a Conferência Internacional sobre Refugiados Centro-americanos (CIREFCA). Nessa reunião extraordinária entre os presidentes na Guatemala, além desse assunto, as Honduras pediram que os grupos guerrilheiros na Nicarágua e FMLN, em El Salvador, fossem desmobilizados para haver maior probabilidade de êxito no processo político (HARTO DE VERA, 1991, p. 218). Tanto esse assunto quanto os avanços na Nicarágua foram discutidos novamente em agosto, quando ocorreu a $\mathrm{V}$ cúpula presidencial.

Quanto a FMLN, após a reunião extraordinária, o comando da guerrilha emitiu um comunicado ${ }^{42}$ que condenou a iniciativa dos presidentes centro-americanos quanto à desmobilização da FMLN, porque estavam ignorando o contexto interno de El Salvador. Esquipulas IV e o encontro em maio de 1989, na Guatemala, compactuavam, no entendimento do comando da FMLN, com as ações do presidente Alfredo Cristiani. Assim, deve-se entender a resposta da FMLN como crítica aos presidentes dos países centro-americanos por desconsiderarem a realidade política de El Salvador. Na verdade, a FMLN reconheceu que, uma vez que a desmobilização e os processos de paz fossem encaminhados, gradativamente a FMLN perderia espaço político em El Salvador. Todavia, o processo de paz de Esquipulas era benéfico para a América Central para que não houvesse retrocesso ao período em que a Doutrina Reagan imperava no financiamento para a escalada do confronto armado. Ademais, as cúpulas presidenciais foram programadas para terem preparação prévia, facilitando e sempre aprovando as declarações por consenso (ROJAS ARAVENA, 1989a, p. 20).

Em continuidade ao encontro da Costa del Sol, registrou-se na Declaração de $\mathrm{Tela}^{43}$, cuja expectativa era de que os grupos armados regionais, em específico a FMLN, se desmobilizassem voluntariamente. Após a reu-

42 O "Texto Resposta da FMLN a Esquipulas IV" foi divulgado no mesmo dia da Declaração de Coronado, em 12 de dezembro de 1989, quando o comando da FMLN certificou-se que a desmobilização das guerrilhas era ponto central do encaminhamento dos processos de paz na América Central. A versão em espanhol do comunicado pode ser lida em: $<$ http://www.envio.org.ni/articulo/619>. Acesso em: $08 \mathrm{dez}$. 2013.

43 Disponível em: <http://www.minex.gob.gt/MDAA/DATA/ MDAA/201011081130043771988-1-16IIIREUNIONORDINARIA(Costa Rica).pdf>. Acesso em: 28 out. 2013. nião, os presidentes dos cinco países assinaram uma carta (S/20791) que formalizou o pedido à Secretaria Geral das Nações Unidas para atuar com a Secretaria Geral da OEA com a finalidade de criar a Comissão Internacional de Apoio e Verificação (CIAV), que cuidaria da desmobilização de grupos armados e guerrilhas. Por parte dos contras, esperava-se que voluntariamente, e com a cooperação dos países vizinhos à Nicarágua, fosse possível desmobilizar, repatriar e reassentar os integrantes da resistência, bem como de seus familiares.

A aprovação da CIAV foi discutida no Conselho de Segurança (S/20857) e consultas ao governo nicaraguense foram necessárias para explicar que o caráter da desmobilização de grupos armados era militar; logo, o Conselho necessitaria aprovar uma missão de observação militar para dividir atribuições com a CIAV (ONU, 2007, p. 130-2 $)^{44}$. Assim, o Conselho de Segurança aprovou o mandato (S/RES/644) da missão da Organização das Nações Unidas da América Central (ONUCA), em 7 de novembro de $1989^{45}$, para que esta cuidasse de monitorar a desmobilização de combatentes, coletar armas e equipamentos militares da resistência nicaraguense, enquanto a CIAV foi responsável pelos aspectos civis do processo de desmobilização, tais como repatriação, assentamento de ex-combatentes, desarmamento e custódia de armas e trabalhos humanitários. Seguindo a recomendação do secretário-geral, o Alto Comissariado das Nações Unidas para os Refugiados (ACNUR) auxiliaria nos trabalhos da CIAV (A/44/344/add.1-S/20699). Percebe-se, portanto, que essa questão foi central para encaminhar a desmobilização dos contras e sandinistas.

A ONUCA estabeleceu sede em Tegucigalpa e direcionou 30 observadores militares que visitaram as capitais dos cinco países. Em todas capitais foram criados escritórios regionais, com exceção de San Salvador, por razões de segurança. O comandante da ONUCA, indicado pela Secretaria Geral da ONU, foi Agustín Quesada

${ }_{44}$ O Repertório de Práticas do Conselho de Segurança foi publicado em 2007 pelo Departamento de Assuntos Políticos (Department of Political Affairs). O trecho do texto também pode ser encontra em versão digital: <http://www.un.org/ en/sc/repertoire/89-92/89-92_05.pdf-page $=58>$. Acesso em: 02 dez. 2012.

45 O Conselho de Segurança recebeu uma carta (S/20642) dos representantes dos cinco países centro-americanos em 31 de março de 1989, solicitando as medidas necessárias para aprovar uma missão de observação militar para monitorar a desmobilização das guerrilhas. 
Gómez e os países que contribuíram com tropas foram Canadá, Colômbia, Espanha, Irlanda, Venezuela e República Federal da Alemanha (SORTO, 2001, p. 229). Posteriormente, quando os mandatos da ONUCA foram renovados, houve substituições por um comandante canadense e novamente um comandante espanhol retornou a liderar a missão (ONU, 2007, p. 130). A missão esteve em campo até 16 de janeiro de 1992.

Em 12 de dezembro de 1989, a Declaração de San Isidro Coronado ${ }^{46}$, ou Esquipulas VI, resultou do encontro da cúpula dos presidentes que novamente apoiaram os trabalhos da CIAV e ONUCA. Nessa cúpula, a Nicarágua reiterou o comprometimento com as eleições e apoiou a desmobilização da resistência nicaraguense. Um elemento inovador registrado na declaração foi o envolvimento da Comunidade Econômica Europeia e do Programa das Nações Unidas para o Desenvolvimento (PNUD), quando ofereceram recursos com a finalidade de mobilizar missões técnicas para o programa de desmobilização de combatentes. O programa aprovado pela agência da ONU e entidade europeia recebeu o nome, tal como consta em Esquipulas VI, de "Plano Especial de Cooperação para a América Central" (Parágrafo $8^{\circ}$ ).

Enquanto evoluíam as negociações nicaraguenses para desmobilizar guerrilhas e, em contrapartida, existia a desmobilização dos contras estacionados perto da fronteira entre a Nicarágua e as Honduras, não se viu o mesmo progresso da FMLN. Parte da explicação esteve atrelada ao início do mandato do presidente Cristiani, no ano de 1989, e à natural resistência que a FMLN tinha em negociar com o governo da ARENA. Assim, resume-se da Declaração de Montelimar ${ }^{47}$, ou Esquipulas VII, que os presidentes incentivaram os governos salvadorenho $\mathrm{e}$ guatemalteco a renovarem vigor com as negociações para pedir a desmobilização da FMLN e URNG.

Após a declaração presidencial de Montelimar, outros encontros geraram mais compromissos. Nas declarações presidenciais emitidas após a de Montelimar houve gradativa transição dos aspectos políticos do processo de paz para os compromissos de cooperação econômica entre os países. Esse foi o reflexo natural da implemen-

${ }_{46}$ Disponível em: <http://www.minex.gob.gt/MDAA/DATA/ MDAA/201011081217477101989-12-12VIREUNION ORDINARIA (Costa Rica).pdf>. Acesso em: 02 jan. 2014.

47 Disponível em: <http://www.minex.gob.gt/MDAA/DATA/ MDAA/201011081322143051990-4-2VIIREUNIONORDINARIA(Nicaragua).pdf>. Acesso em: 02 jan. 2014. tação de Esquipulas II, sendo a cooperação econômica e o desenvolvimento parte do ponto 9 do acordo. Como foram diversas as reuniões entre os presidentes, consigna-se todas as reuniões de cúpula no quadro abaixo, com cidades e datas, para melhor visualização da evolução do processo de Esquipulas:

\begin{tabular}{|l|l|}
\hline \multicolumn{2}{|c|}{$\begin{array}{c}\text { Quadro 3: Cúpulas Presidenciais Centro-americanas } \\
(1986-1992)\end{array}$} \\
\hline Esquipulas I & Guatemala, maio de 1986 \\
Esquipulas II & Guatemala, agosto de 1987 \\
Alajuela & Costa Rica, janeiro de 1988 \\
Costa del Sol & El Salvador, fevereiro de 1989 \\
Tela & Honduras, agosto de 1989 \\
San Isidro de Coronado & Costa Rica, dezembro de 1989 \\
Montelimar & Nicarágua, abril de 1990 \\
Antígua & Guatemala, junho de 1990 \\
Puntarenas & Costa Rica, dezembro de 1990 \\
San Salvador & El Salvador, junho de 1991 \\
Tegucigalpa & Honduras, dezembro de 1991 \\
Managua & Nicarágua, junho de 1992 \\
Ciudad de Panamá & Panamá, dezembro de 1992 \\
\end{tabular}

Fonte: Elaboração própria.

Antígua $^{48}$, o Panamá participou pela primeira vez como membro observador da reunião de cúpula. Neste encontro, o tom acusatório contra a Nicarágua deixou de existir porque houve eleições organizadas no país no início de 1990, sinalizando nova conjuntura política para os nicaraguenses e para os países vizinhos. Outro ponto favorável à Nicarágua foi o fato de terem chegado a reunião de Antígua com a conquista de terem desmobilizado 50\% do exército (HARTO DE VERA, 1991, p. 230). Na sequência, em Puntarenas ${ }^{49}$, salientou-se que, além da declaração dos presidentes sobre o encaminhamento dos compromissos de Esquipulas II, os presidentes também produziram uma declaração sobre El Salvador, solicitando que a FMLN deixasse de atuar e iniciasse negociações e desmobilização (SORTO, 2001, p. 223).

É certo que Esquipulas II e as reuniões dos presidentes foram conturbadas, com numerosas propostas e entraves. Mas, acima de tudo, seguiram com a firme finalidade de colocar fim a possibilidade de intervenção militar na Nicarágua, que era a pior opção para todos os países centro-americanos e talvez para os Estados Uni-

48 Declaração de Antígua está disponível em: <http://www.sice. oas.org/SICA/CumbreAntigua90.pdf $>$. Acesso em: 02 jan. 2014

49 Declaração de Puntarenas está disponível em: <http://www. uca.edu.sv/revistarealidad/archivo/4e7753a163b39declaracion.pdf >. Acesso em: 02 jan. 2014. 
dos. Assim, pode-se dizer que Esquipulas II encaminhou esse processo, mas era insuficiente para resolver questões específicas na Nicarágua, Guatemala e El Salvador. Nesse sentido, processos de mediação foram conduzidos pela ONU e pela OEA para que fosse possível alcançar uma solução definitiva ${ }^{50}$. O Conselho de Segurança manifestou apoio a Esquipulas II e ao que foi acordado nas declarações presidenciais subsequentes (S/RES/637), em 27 de julho de 1989.

Em 25 de fevereiro de 1990, a ONU enviou uma missão para monitorar as eleições na Nicarágua, a pedido do governo do país. Ademais, registrou-se em publicação do Departamento de Informação Pública da ONU (1995, p.58) que a Organização enviou uma operação a El Salvador, em julho de 1991, para monitorar o cumprimento do acordo entre o governo salvadorenho e a Frente Farabundo Martí para a Libertação Nacional. Por último, também consta na referida publicação do Departamento de Informação Pública da ONU (1995, p. 60-2) que houve empenho da Organização para monitorar a reconciliação nacional, promover o cessar fogo e acompanhar o cumprimento dos direitos humanos na Guatemala com o envio de uma operação em janeiro de 1997. Entende-se que essas operações de paz conformaram o ciclo de encerramento do que foi semeado por Esquipulas II.

Ao analisar as medidas da ONU no início dos anos 1990, Fox (2004) analisou que as ações promovidas pelo Conselho de Segurança consubstanciaram-se na tentativa de consolidar regimes políticos democráticos com uma série de medidas, como a organização de eleições; a promoção de processos de reconciliação nacional; o provimento de segurança interna - dando consequentemente estabilidade regional - auxílio para a reconstrução das instituições políticas e recuperação econômica e social dos países. Essas ações enumeradas compõem uma espécie de padrão pelo qual o organismo internacional propunha soluções aos conflitos domésticos e para países que se recompunham de guerras civis.

A operação de manutenção de paz enviada a El Salvador (ONUSAL), em julho de 1991, e que permaneceu até 1995, ocorreu de acordo com o parâmetro descrito por Fox (2004). Um dos objetivos da ONUSAL era o envio do contingente militar para monitorar o cum-

50 A solução definitiva vislumbrada por Estados Unidos era a desmobilização de guerrilhas e encaminhamento de eleições, o que foi compactuado pelas Organizações Internacionais. primento do acordo entre o governo de El Salvador e a Frente Farabundo Martí de Libertação Nacional. Eram pontos do mandato da ONUSAL: o cessar fogo, reformar e reduzir integrantes das forças armadas, criar uma nova força policial, reformar os sistemas judicial e eleitoral, verificar o cumprimento de respeito aos direitos humanos e prestar auxílio econômico e social ao país (S/RES/693).

Assim, num primeiro momento, o Grupo dos Oito e, posteriormente, as cúpulas centro-americanas foram muito importantes para encaminhar processos conjuntos de pacificação. É fato que o final da Guerra Fria também favoreceu o desfecho pacífico, pois, com o fim da União Soviética, os países aliados perderam força. Assim, o constante incentivo que vinha de Cuba também se tornou insustentável e as guerrilhas centro-americanas não teriam outra fonte de sustento logístico e catalisação de recursos.

No início dos anos 1990, coube à ONU e ao Conselho de Segurança ponderar especificamente as desavenças locais e nutrir os governos com assessorias de missões técnicas, recursos e mandatos especializados que finalizassem os processos de reconciliação nacional. O enviado especial da Secretaria Geral da ONU para El Salvador foi Álvaro de Soto, que iniciou o árduo diálogo entre FMLN e governo (HARTO DE VERA, 1991, p. 226). Processo semelhante, com a participação da ONU, também aconteceu na Nicarágua e na Guatemala.

\section{Considerações finais}

Pode-se afirmar que o desfecho do conflito na América Central foi próximo ao vislumbrado nas primeiras iniciativas de países latino-americanos. Impulsionada por Contadora, a via pacífica buscou reunir os principais países interessados no fim do conflito centro-americano, endossados por México, Panamá e demais países da América do Sul. A facilitação dos diálogos proporcionados pelos encontros do Grupo de Contadora evidenciou a capacidade de articulação da administração Reagan de influenciar os países centro-americanos, principalmente Honduras, Costa Rica e El Salvador a não cooperar com a via pacífica enquanto os sandinistas não sucumbissem. Tal foi o impulso do Grupo de Tegucigalpa. Todavia, desmoralizados internacionalmente após a revelação do incidente Irã-contras, os Estados Unidos não puderam mais insistir na vitória militar contra as guerrilhas. Dessa maneira, investiram na liderança costa-riquenha do 
presidente Óscar Arias para encaminhar novo processo de paz, facilitado a partir de Esquipulas II. Desse ponto em diante, as negociações tomaram escopo regional, incentivados por diversos países e organizações regionais, mas com respostas proporcionadas pelos presidentes nas diversas cúpulas organizadas. Por fim, quando a transição de governo nicaraguense possibilitou o ensejo do primeiro programa de desmobilização de grupos armados, outros países, tais como El Salvador e Guatemala, também foram incentivados a assinar acordos de paz que pusessem fim a luta armada. Nesse aspecto, e com o fim da Guerra Fria, a ONU foi responsável por articular as partes em litígio (governos e guerrilhas) para incentivar na mesa de negociações o fim da guerra civil. Assim, com desenlace distinto do planejado pelos Estados Unidos, a solução pacífica e regional foi aquela que melhor consignou interesses diversos e fez esmorecer o furor revolucionário por meio de concessões oferecidas pelos governos.

\section{Referências}

AGUILERA PERALTA, G. Esquipulas y el conflicto interno en centroamérica. Anuario de Estudios Centroamericanos, San José, Universidad de Costa Rica, v. 14, n. 1-2, p. 131-141, 1988.

ALCÁNTARA SÁEZ, M. Sistemas políticos de América Latina: México, América Central y Caribe. Madrid: Tecnos, 2008. v. 2.

ANNUNZIATA, L. Democrats and the Arias Plan. The Nation, v. 244, n. 15, Nova Iorque, p. 503-506, 18 abr. 1987.

ARNSON, C. J. Crossroads: Congress, the President, and Central America. 2. ed. University Park: The Pennsylvania State University Press, 1989.

ASSEMBLEIA GERAL DAS NAÇÕES UNIDAS. A/44/344/add.1-S/20699. Nova Iorque, 9 de outubro de 1989.

BAGLEY, B. M. Contadora: the failure of diplomacy. Journal of Interamerican Studies and World Affairs, Flórida, v. 28, n. 3, p. 1-32, out. 1986.

BATISTA, E. S. América Central nas asas do quatzal. Porto Alegre: Literalis, 2003.

BOBBIO, N. O futuro da democracia: uma defesa das regras do jogo. Rio de Janeiro: Paz e Terra, 1986.

BOBBIO, N; MATTEUCCI, N.; PASQUINO, G. Dicionário de política. Brasília: Editora da Universidade de Brasília, 1998.
BRENES, A. C. Costa Rica: una democracia sitiada por el lobo feroz. Nueva Sociedad, Buenos Aires, n. 80, p. 11-15, nov-dez 1985

CALLONI, S.; CRIBARI, R. La "guerra encubierta" contra Contadora. Panamá: Centro de Capacitación Social, 1983.

CANDANEDO, R. "La comisión internacional de verificación del acuerdo Esquipulas 2 inicia su labor". El País. Arquivo digital. 05 jan. 1988.

CARAVEO TOLEDO, R. B. El interés nacional mexicano en Centroamérica y el Grupo Contadora. 1984. 173f. Tesina (Licenciatura em Ciência Política). Universidad Autónoma Metropolitana, Iztapalapa, 1984.

COMMITEE ON FOREIGN RELATIONS. Report of the National Bipartisan Commission on Central America. Washington, 10 jan. 1984.

CONSELHO DE SEGURANÇA DAS NAÇÕES UNIDAS. S/RES/637. Nova Iorque, 27 de julho de 1989.

CONSELHO DE SEGURANÇA DAS NAÇÕES UNIDAS. S/RES/644. Nova Iorque, 7 de novembro de 1989.

CONSELHO DE SEGURANÇA DAS NAÇÕES UNIDAS. S/RES/693. Nova Iorque, 20 de maio de 1991.

DANA SIMS, H.; PETRASH, V. The Contadora Peace Process. Conflict Quarterly, p. 05-28, out. 1987.

DEPARTAMENTO DE INFORMAÇÃO PÚBLICA. Basic facts about the United Nations. Nova Iorque: ONU, 1995.

FOX, G. Democratization. In: MALONE, D. (Org). The UN Security Council: from the Cold War to the $21^{\text {st }}$ century. Londres: Lynne Rienner Publishers, 2004. p. 69-84.

GLEIJESES, P. Reflexiones sobre la victoria de los Estados Unidos en Centroamérica. Revista Iberoamericana, Madrid, v. 19, p. 257-269, jan./jun. 1991.

GOODFELLOW, W. Reagan vs. the Sandinistas: the undeclared war on Nicaragua. Washington, DC: Center for International Policy, 1986.

GRANDIN, G. A revolução guatemalteca. São Paulo: Editora Unesp, 2004.

GREENBERGER, R. Reagan administration moves to limit treaty 'ploy' by Nicaraguan marxists. The Wall Street Journal, Nova Iorque, 26 set. 1984a.

GREENBERGER, R. Shultz Nicaragua trip is faulted by some as step to quiet critics, not spur talks. The Wall Street Journal, Nova Iorque, 4 jun. 1984b. 
GRUPO DE CONTADORA. Declaração de Cancun. Cancun, 17 de julho de 1983.

GRUPO DE CONTADORA. Declaração de Caraballeda. Caraballeda, 12 de janeiro de 1986.

HARTO DE VERA, F. Los procesos de negociaciones de paz en America Central. 1991. 357f. Tesina (Doutorado em História) - Universidad Complutense de Madrid, Madrid, 1991.

I CUMBRE DE PRESIDENTES CENTROAMERICANOS. Esquipulas I. Esquipulas, 24 e 25 de maio de 1986.

II CUMBRE DE PRESIDENTES CENTROAMERICANOS. Esquipulas II. Ciudad de Guatemala, 7 de agosto de 1987.

III CUMBRE DE PRESIDENTES CENTROAMERICANOS. Declaração de Alajuela. Costa Rica, 16 de janeiro de 1988.

IV CUMBRE DE PRESIDENTES CENTROAMERICANOS. Declaração de Costa del Sol. Costa del Sol, 13 e 14 de fevereiro de 1989.

V CUMBRE DE PRESIDENTES CENTROAMERICANOS. Declaração de Tela. Tela, 7 de agosto de 1989.

VI CUMBRE DE PRESIDENTES CENTROAMERICANOS. Declaração de San Isidro de Coronado. San Isidro de Coronado, 10-12 de dezembro de 1989.

VII CUMBRE DE PRESIDENTES CENTROAMERICANOS. Declaração de Montelimar. Montelimar, 2 e 3 de abril de 1990.

VIII CUMBRE DE PRESIDENTES CENTROAMERICANOS. Declaração de Antigua. Antigua, 17 de junho de 1990.

IX CUMBRE DE PRESIDENTES CENTROAMERICANOS. Declaração de Puntarenas. Puntarenas, 17 de dezembro de 1990.

X CUMBRE DE PRESIDENTES CENTROAMERICANOS. Declaração de San Salvador. San Salvador, 15-17 de julho de 1991.

XI CUMBRE DE PRESIDENTES CENTROAMERICANOS. Declaração de Tegucigalpa. Tegucigalpa, 13 de dezembro de 1991.

XII CUMBRE DE PRESIDENTES CENTROAMERICANOS. Declaração de Managua. Managua, 5 de junho de 1992.

XIII CUMBRE DE PRESIDENTES CENTROAMERICANOS. Declaração de Panamá. Ciudad de Panamá, 11 de dezembro de 1992.
LÓPEZ HERNANDÉZ, J. A. América Central: conflito e solução negociada na década de oitenta. 1993. 210f. Dissertação (Mestrado em Relações Internacionais) - Universidade de Brasília, Brasília, 1983.

LYNCH, E. A. The Cold War's last battlefield: Reagan, the Soviets, and Central America. Albany: State University of New York Press, 2011.

MAIRA, L. Por que centroamerica?. In: MAIRA, L. (Org.). La política de Reagan y la crisis en Centroamérica. San José: EDUCA, 1982. p. 201-214.

MALLMANN, M. I. Os ganhos da década perdida: democracia e diplomacia na América Latina. Porto Alegre: EDIPUCRS, 2008.

MIRANDA, R.; RATLIFF, W. The civil war in Nicaragua: inside the sandinistas. Nova Jersei: Transaction Publishers, 1994.

MONTGOMERY, T. S.; WADE, C. A revolução salvadorenha. São Paulo: Unesp, 2006.

OJEDA GOMÉZ, M. Retrospección de Contadora: los esfuerzos de México para la paz en Centroamérica, 19831985. Ciudad de México: El Colegio del México, 2007.

OPAZO BERNALES, A.; FERNÁNDEZ VÁSQUEZ, R. Esquipulas II: una tarea pendiente. San José: EDUCA, 1990.

ORGANIZAÇÃO DAS NAÇÕES UNIDAS (ONU). Ata de Contadora para a Paz e Cooperação na América Central. Declaração de Cartagena. Cartagena das Índias, 22 de novembro de 1984.

ORGANIZAÇÃO DAS NAÇÕES UNIDAS (ONU). Repertoire of the Practice of the Security Council: Supplement 1989-1992. Nova Iorque: United Nations Publications, 2007.

PURCELL, S. Demystifying Contadora. Foreign Affairs, Nova Iorque, v. 6, n. 4, p. 74-95, out. 1985.

ROJAS ARAVENA, F. El proceso de Esquipulas: el desarollo conceptual y los mecanismos operativos. Trabalho apresentado na CLACSO. Caracas, 27-29 mar 1989a.

ROJAS ARAVENA, F. El proceso de Esquipulas: el desarollo conceptual y los mecanismos operativos. Estudios Internacionales, Santiago, v. 22, n. 86, p. 224-247, abr-jul. $1989 \mathrm{~b}$.

ROJAS ARAVENA, F. Esquipulas II: un proceso de construccion de confianza. Revista Relaciones Internacionales, Costa Rica, v. 46, p. 9-22, primero semestre de 1994. 
ROUQUIÉ, A. Guerras y paz en América Central. Cidade do México: Fondo de Cultura Económica, 1994.

SECRETARIA GERAL DAS NAÇÕES UNIDAS. S/20642. Nova Iorque, 18 de maio de 1989.

SECRETARIA GERAL DAS NAÇÕES UNIDAS. S/20791. Nova Iorque, 16 de agosto de 1989.

SECRETARIA GERAL DAS NAÇÕES UNIDAS. S/20857. Nova Iorque, 21 de setembro de 1989.

SORTO, F. O. A Corte Internacional de Justiça e o caso Estados Unidos-Nicarágua. Revista de Informação Legislativa, Brasília, ano 32, n. 127, p. 233-239, jul./set. 1995.

SORTO, F. O. Guerra civil contemporânea: a ONU e o caso salvadorenho. Porto Alegre: S. A. Fabris Editor, 2001.
TAUBMAN, P. Latin peace plans: why the US Balks. The New York Times, Nova Iorque, out 1984.

TREIN, F. A vontade do poder hegemônico: a política externa de Reagan. Ensaios FEE, Porto Alegre, v. 3, n. 2, p. 57-66, jan-jul. 1983.

VICKERS, G. R. Keeping the peace: the history and challenges of the accords. Harvard International Review, Cambridge, v. 17, n. 2, summer 1995.

WICKER, T. In the Nation; cat out of the bag. The New York Times, Nova Iorque, 14 jan. 1988.

ZIMMERMANN, M. A revolução nicaraguense. São Paulo: Unesp, 2006. 